\title{
Effects of bed-material gradation on clear water scour at single and group of piles
}

\author{
Saeid Okhravi ${ }^{1,2^{*}}$, Saeed Gohari ${ }^{1}$, Mahdi Alemi ${ }^{3,4}$, Rodrigo Maia ${ }^{3,4}$ \\ ${ }^{1}$ Department of Water Engineering, College of Agriculture, Bu-Ali Sina University, 65178-38695, Hamadan, Iran. \\ ${ }^{2}$ Current Address: Institute of Hydrology, Slovak Academy of Sciences, Dúbravská cesta 9, 84104, Bratislava, Slovak Republic. \\ ${ }^{3}$ Departamento de Engenharia Civil, Faculdadede Engenharia, Universidade do Porto, Rua Dr. Roberto Frias, Porto 4200-465, Portugal. \\ ${ }^{4}$ CIIMAR - Interdisciplinary Centre of Marine and Environmental Research, University of Porto, Terminal de Cruzeiros do Porto de \\ Leixões, Avenida General Norton de Matos, 4450-208, Matosinhos, Portugal. \\ *Corresponding author. Tel.: +98-9131864149. E-mail: s.okhravi94@basu.ac.ir; saeid.okhravi@savba.sk
}

\begin{abstract}
This study presents the results of 32 laboratory experiments on local scour at a single pile and a $1 \times 4$ pile group for both uniform and non-uniform sediments under clear water conditions. The present study aims to evaluate the effects of different sediment beds made up of mixtures of sand and gravel (four-bed configurations) in $d_{50}(1-3.5 \mathrm{~mm}$ ) and gradation (1.4-3) ranges on scour depth for different flow discharges and flow depths. Further, the findings of the experiments are deployed to describe the effects of pile spacing and flow conditions on the local pier scour for both uniform and non-uniform bed granulometries. In addition, this study addresses the performance of some existing scourdepth predictors. Also, the corresponding results are suitable for validating the numerical models in local pier scour prediction importantly with non-uniform sediments. In summary, the results show that effects of sediment gradation dampen with increasing flow shallowness. Furthermore, the maximum scour depth at pile groups generally increases as pile spacing decreases for uniform sediments, whereas the mentioned trend was not observed for non-uniform sediments for the same flow and sediment conditions. Moreover, the experimental results revealed that bed sediment gradation is a controlling factor in the pile's scour. Thus, the existing scour depth predictions could be highly improved by considering sediment gradation in the predictions. Finally, the conclusions drawn from this study provide crucial evidence for the protection of bridge foundations not only at the front pile but also at rear piles.
\end{abstract}

Keywords: Laboratory tests; Local scour; Pile groups; Pile spacing; Sediment gradation; Uniform and non-uniform sediments.

\section{INTRODUCTION}

The study of bridge pier scour is maturing, with a wealth of well-understood methods dealt with laboratory scale experimental studies on single pier scour. Research into clear water single pier scour has provided different approaches for scour predictions based on the understanding of flow-sediment-pier interactions (Ettema et al., 2017). According to the early study of Laursen (1963) on local pier scour, the scour process depends on the characteristics of the flow field (flow depth and bed shear stress), the sediment (critical shear stress for sediment entrainment), and the structure (pier width/diameter). In the last two decades, Melville and Coleman (2000), Sumer and Fredsøe (2002), and Ettema et al. (2011) have provided comprehensive summaries of local pier scour. A majority of those experimental studies have used fine uniform sand for the channel bed. While, in nature, the river bed material generally consists of mixtures of sand and gravel. It is noteworthy to mention that, in a nonuniform sediment mixture, the fine particles start moving earlier compared to the coarse particles due to unequal mobility of sand and gravel, which makes the bed surface to be armored (Wilcock and DeTemple, 2005). There have been relatively few studies reported in the literature relating to the scour in complex mixtures of sediments. For example, Raudkivi and Ettema (1977), Chiew and Melville (1989), and Dey and Raikar (2005) examined the effects of non-uniform sediments on equilibrium scour depths around bridge piers under both clear water and live bed conditions. The corresponding results show that the equilibrium scour depth with armored surface beds is less than the equilibrium scour depth in uniform sediment beds with the same $d_{50}$ (median grain size). Researches of Molinas (2001) and Diab (2011) have also shown that scouring process and scour hole geometry are affected by the composition of armor layer. The study of Sui et al. (2010) on clear-water scour around semi-elliptical abutments for the armored channel beds showed that the scour hole extension decreases as armor layer was being coarsened. Besides, the structure of armor layer is influenced by the flow rate. The experimental observations of Okhravi et al. (2019) revealed that with increasing the flow rate, the armor layer became coarser, as more and more of the sediment particles are transported by the flow. The recent relevant studies of Mir et al. (2018) and Namaee and Sui (2019) on the local pier scour pointed out that scour depth predictors for the cases of realistic field conditions (i.e., river bed) should incorporate at least both sediment gradation $\left(\sigma_{\mathrm{g}}\right)$ and $d_{50}$ to predict maximum scour depth with a higher degree of accuracy.

The above-referred studies were mostly based on considering a single pile/pier. The local scour mechanism at pile groups can be more complicated than that of a single pile due to the interaction of vortices generated at individual piles and to the interdependence of secondary scour holes formed around each pile (Alemi et al., 2019). It is noteworthy to note that a group of piles can represent, for example, a pile-supported pier when the water level is way below the level of the pile cap, meaning that only the piles are exposed to the approaching flow. 
Previous studies in the case of pile groups were limited to the uniform sediments and suggested different equations to calculate an equivalent pier width to substitute the pier width in the single- pier scour equations (e.g., Ataie-Ashtiani and Beheshti, 2006; Coleman, 2005; Moreno et al., 2016; Sheppard and Renna, 2010; Yang et al., 2020). To the best of the author's knowledge, no prior studies have examined local scour around group of piles in non-uniform sediments. Hence, it is not yet well understood how complex mixtures of sediments and the following armor layer actually influence scour pattern at pile groups especially at rear piles in tandem arrangement. This paper addresses maximum depth, length, and width of the scour hole near the front and rear piles in non-uniform sediment beds, far lacking in the scientific literature.

The literature review has shown that local scour depth at pile groups under clear water condition for fully developed flow with non-ripple forming sediments $\left(d_{50}>0.6 \mathrm{~mm}\right)$ can be described by the following dimensionless parameters (e.g., Arneson et al., 2012; Ataie-Ashtiani et al., 2010; Lança et al., 2013b):

$\frac{d_{\mathrm{Sm}}}{d_{\mathrm{p}}}=\varphi\left(K_{\mathrm{h}} ; K_{\mathrm{I}} ; K_{\mathrm{d}} ; K_{\mathrm{t}} ; K_{\mathrm{sp}} ; K_{\mathrm{s}} ; K_{\theta} ; \sigma_{\mathrm{g}} ; m ; n\right)$

where $\varphi$ characterizes a function; $d_{\mathrm{Sm}}=$ maximum scour depth at instant $t$ for a pile group; $d_{\mathrm{p}}=$ individual pile width or diameter; $K_{\mathrm{h}}=h / d_{\mathrm{p}}=$ flow shallowness; $K_{\mathrm{d}}=d_{\mathrm{p}} / d_{50}=$ sediment coarseness; $K_{\mathrm{I}}=u / u_{\mathrm{c}}=$ flow intensity; $h=$ upstream flow depth; $u=$ average approach flow velocity; $u_{\mathrm{c}}=$ ultimate mean flow velocity for the incipient motion of sediment particles; $K_{\mathrm{t}}=$ time factor; $K_{\mathrm{sp}}=s / d_{\mathrm{p}}=$ pile spacing factor; $s=$ distance between the center of each neighbor piles; $K_{\mathrm{s}}$ and $K_{\theta}=$ coefficients expressing pile shape and alignment of the individual piles; $m$ and $n=$ the number of rows and columns in group of piles; $\sigma_{\mathrm{g}}=$ $\sqrt{\left(d_{84} / d_{16}\right)}=$ gradation coefficient of the material forming the bed, where $d_{84}$ and $d_{16}$ are the grain sizes that are coarser than $84 \%$ and $16 \%$ of the bed material by weight, respectively.

In the present study, in order to turn simple and clear the reference to the pile group, the piles arrangement was considered fixed in all experiments ( $m=4$ and $n=1)$, facilitating to investigate the impacts of non-uniform sediments on $d_{\mathrm{Sm}}$. The assessments were performed for different piles spacing. A specific relation, $K_{\mathrm{Sg}}=d_{\mathrm{Sm}} / d_{\mathrm{Sr}}$, is defined as a pile spacing index at pile group with the concept that scour process evolves through time $\left(d_{\mathrm{Sr}}=\right.$ maximum scour depth at the single reference pile for the same $t$ and same hydrodynamic conditions). Another important point is that bed-armoring degree for non-uniform material can be affected by different values of $h / d_{\mathrm{p}}$ with direct influences on the scouring process. Finally, for single cylindrical piles with no skew-angle $\left(K_{\mathrm{s}}=K_{\theta}=1\right)$ and flow intensity close to unity, Eq. (1) becomes

$K_{\mathrm{Sg}}=\frac{d_{\mathrm{Sm}}}{d_{\mathrm{Sr}}}=\varphi\left(\frac{h}{d_{\mathrm{p}}} ; \frac{d_{\mathrm{p}}}{d_{50}} ; \frac{s}{d_{\mathrm{p}}} ; \sigma_{\mathrm{g}}\right)$

In summary, the aim of this study is to assess the effects of sediment size and gradation in complex sediment mixtures on the scour depth at a single pile and at pile group under different flow condition. In the present study, two non-uniform sediments and two uniform sediments are deployed to appraise the development of armor coat at the upstream flow bed and inside the scour hole around single pile and four in-line circular piles in tandem arrangement. The single pile case was considered to be used as a reference case to the pile groups study. Moreover, in view of the quality of the present data set, the results of the single pile experiments are compared with those obtained by Melville and Coleman (2000) and Guo (2012). The study also aims at providing reference experimental data for the validation of the numerical models in which non-uniform sediment is considered in the local pier scour simulation. Finally, the currently available methodologies for scour depth prediction at pile groups are evaluated using the collected set of data in terms of adequacy of the predictors for non-uniform bed granulometries.

\section{Methods for local scour depth prediction at pile-supported piers}

There are some methods developed to predict equilibrium local scour depth at bridge piers with complex pier geometries (i.e., pile-supported pier), under clear water flow conditions. Presently, three methods of (1) Auckland reported by Melville and Coleman (2000), and Coleman (2005); (2) Florida Department of Transportation (FDOT) reported by (Sheppard and Renna, 2010); and, (3) Federal Highway Administration, Hydraulic Engineering Circular No. 18, HEC-18 reported by Richardson and Davis (2001) and Arneson et al. (2012) are well documented and acknowledged. A complete explanation for these predictors is quite lengthy as they include several equations with multiple variables and factors. Hence, a more comprehensive description can be found in the bibliographic references discussed along with this section.

Melville and Coleman (2000) proposed a procedure for complex piers to predict $d_{\mathrm{Sm}}$, by characterizing different combinations of pier components. The method is based on the assumption that the complex pier can be represented by a single pile with an 'equivalent pier diameter' defined by $d_{\text {pe }}$. The $d_{\text {pe }}$ is the diameter of a single circular pile that would produce the same scour depth as the complex pier, for the same sediment and flow conditions. According to the pile group arrangement of this study, $d_{\mathrm{pe}}$ is the effective diameter of the one group of four piles aligned with the flow. Melville and Coleman (2000) suggest the following equation for computing $d_{\mathrm{Sm}}$. The equation formulated as a product of various $K$-factors is given as

$$
d_{\mathrm{Sm}}=K_{\mathrm{h} d_{\mathrm{pe}}} K_{\mathrm{d}} K_{\mathrm{I}} K_{\mathrm{s}} K_{\theta} K_{\mathrm{t}}
$$

where $K_{\mathrm{h} d_{\mathrm{pe}}}=$ flow shallowness factor which depends on $d_{\mathrm{pe}}$.

The method of HEC-18 predicts pile group equilibrium scour depth $\left(d_{\text {Sme }}\right)$ using the following equation, Eq. (4):

$$
\frac{d_{\text {Sme }}}{h}=2 K_{\mathrm{s}} K_{\theta} K_{\text {bed }} K_{\mathrm{a}}\left(\frac{d_{\mathrm{pe}}}{h}\right)^{0.65} \mathrm{Fr}^{0.43}
$$

where $\mathrm{Fr}=u /(\mathrm{g} h)^{0.5}=$ approach flow Froude number; $K_{\mathrm{s}}=$ correction for pile shape which is unity for circular piles; $K_{\text {bed }}=$ correction for bed form which equals to 1.1 for clear water scour; $K_{\mathrm{a}}=$ correction of sediment mixtures (Richardson and Davis, 2001).

Concerning the so-called FDOT method, Sheppard et al. (2004) recommended that the total $d_{\mathrm{pe}}$ for the structure of the complex pier can be determined by the sum of the effective diameters of the components making up the structure. Since the pile-supported-pier is used in this study, the formulations developed for pile groups is only applied to compute $d_{\mathrm{pe}}$ and $d_{\text {Sme }}$ (Sheppard and Renna, 2010). In accordance to this method, the equation is formulated for equilibrium scour depth prediction as

$\frac{d_{\text {Sme }}}{d_{\mathrm{pe}}}=2.5 K_{\mathrm{h} d_{\mathrm{pe}}} K_{\mathrm{I}} K_{\mathrm{d}}$ 
In local pier scour experiments with non-uniform sediment mixtures, like those performed in the present study, bed armoring is a predominant phenomenon, so the current work focused on the predictors whose variables include the bed material gradation effects (e.g., Melville and Coleman, 2000).

\section{Experimental setup and procedure}

The experiments on local pile scour were conducted in a rectangular tilting flume at the hydraulic laboratory of the Faculty of Agriculture at Bu-Ali Sina University (Hamadan, Iran). The flume was $0.5 \mathrm{~m}$ wide, $10.5 \mathrm{~m}$ long, and $0.5 \mathrm{~m}$ deep. Water flowing enters into an upstream reservoir equipped with a screen and perforated bricks in a grid to smooth flow trajectories and to guarantee a transversal uniform flow distribution. Immediately following the referred flow straightening, a zone of coarse gravels, $2.5-\mathrm{m}$-long, was prepared to provide highbed friction and to secure a fully developed turbulent boundary layer to be formed before the test section. Moreover, the entrance length of the channel was estimated theoretically for greater confidence. The corresponding value(s) was (were) less than the upstream length of the channel (i.e., distance between the pier and inlet section). The water depth was regulated through an adjustable tailgate at the downstream end of the flume. Flow discharge was measured by an ultrasonic flow meter located at the feeder pipe with a full-scale accuracy of $\pm 1 \%$. The piles were placed in the middle of a recess box ( $3 \mathrm{~m}$ long), located $3.5 \mathrm{~m}$ downstream of the flume inlet. The box was deep enough to model local scour to a depth of $0.15 \mathrm{~m}$.

For all experiments, smooth Teflon pipes with a diameter $\left(d_{\mathrm{p}}\right)$ of $0.04 \mathrm{~m}$ were used to simulate cylindrical piles placed at the centerline of the flume. The configurations of the pile group used in this study consisted of a single alignment of four piles, each configuration with a different pile spacing. In total, piles arrangement type were named $\mathrm{S}_{1}$ for the single pile; and $\mathrm{S}_{2}, \mathrm{~S}_{3}$, and $\mathrm{S}_{4}$ for three pile group configurations with different piles spacing $s / d_{\mathrm{p}}=2,3$, and 4 , respectively (see Fig. 1).

Four different sediment mixtures, named $\mathrm{C}_{1}$ to $\mathrm{C}_{4}$, with different $d_{50}$ and $\sigma_{\mathrm{g}}$ were used for this study, two with uniform sediments $\left(\sigma_{\mathrm{g}}<1.5\right)$ and two with non-uniform sediments $\left(\sigma_{\mathrm{g}}>\right.$ 1.5). Table 1 represents the sediment properties for different sediment bed configurations. Also, particle size distribution curves for four bed configurations are shown in Fig. 2. For nonuniform sediments, an artificial trimodal sediment mixture was used for sediment beds composition. The two non-uniform sediment mixtures were composed of a sand fraction ( 0.6 up to $2 \mathrm{~mm}$ ) and two gravel fractions: a medium fraction (2-4.75 $\mathrm{mm})$, and a coarse fraction $(4.75-9.5 \mathrm{~mm})$. The selected four sediment beds with three different values of $d_{50}$ (about 1,2 , and $3.5 \mathrm{~mm}$ ) and $\sigma_{\mathrm{g}}$ (about 1.4, 2, and 3) provide the possibility to evaluate the impacts of sediment gradation $\left(\sigma_{\mathrm{g}}\right)$ and sediment size $\left(d_{50}\right)$ on the maximum scour depth and scour hole geometry. In fact, based on the prior studies by Lança et al. (2013a), Lee and Sturm (2009), Sheppard et al. (2004), and Melville and Chiew (1999) local scour depths observed in this study are influenced by the sediment coarseness as $d_{\mathrm{p}} / d_{50}<50$. It is worth noting that the flume sediment bed configurations are similar to the upper and middle river reaches where different sediment size fractions are exposed to the flow and the river bed are gradually being armored. Hence, the findings of the present study cannot be applied to the lower reaches of the river bed where the armor coat has already been formed.

The experiments were set up under a subcritical flow regime with two steady flow discharges of $20 \mathrm{~L} / \mathrm{s}\left(\mathrm{Q}_{1}\right)$ and $35\left(\mathrm{Q}_{2}\right) \mathrm{L} / \mathrm{s}$ (characterized by different flow shallowness $\left(h / d_{\mathrm{p}}\right)$, when flow intensity $\left(u / u_{c}\right)$ was kept unchanged). The critical flow condition was estimated based on the criteria suggested by Melville and Coleman (2000). The experiments were carried out on clear water condition at threshold flow intensity $u / u_{\mathrm{c}} \approx 0.9$ for uniform sediments. For a non-uniform sediment bed, the ratio $u / u_{\mathrm{a}}$ ( $u_{\mathrm{a}}$ is the average approaching flow velocity at armor peak) indicates the transition state from clear water to live bed scour conditions. Therefore, similar threshold flow intensity $u / u_{\mathrm{a}} \approx 0.9$ was considered fixed for non-uniform sediments. To determine $u_{\mathrm{a}}$, the method of Melville and Coleman (2000) was used.

The flume was provided with a carriage (top of the flume), which could be moved upstream or downstream. A laser meter was mounted on the carriage for the bed bathymetry at the end of each experiment. In addition, a handheld point gauge with an accuracy of $\pm 1 \mathrm{~mm}$ was used for measurements of the scour depth during the experiments. To visualize the bed topography, more than 2300 bathymetry points were collected for each test with an average distance of $1 \mathrm{~cm}$ between the measuring points.

The duration of the experimental runs was $8 \mathrm{~h}$. Nevertheless, some runs lasted $24 \mathrm{~h}$ to investigate the time required to achieve the equilibrium scour condition. According to the obtained results, $0.9 d_{\mathrm{Sr}}(t=24 \mathrm{~h})$ was observed after $6-8 \mathrm{~h}$ in the tests with uniform sediments and after $2-3 \mathrm{~h}$ in non-uniform sediment beds. In other words, for example in our reference test, the increment of the scour depth after $8 \mathrm{~h}$ until $24 \mathrm{~h}$ was
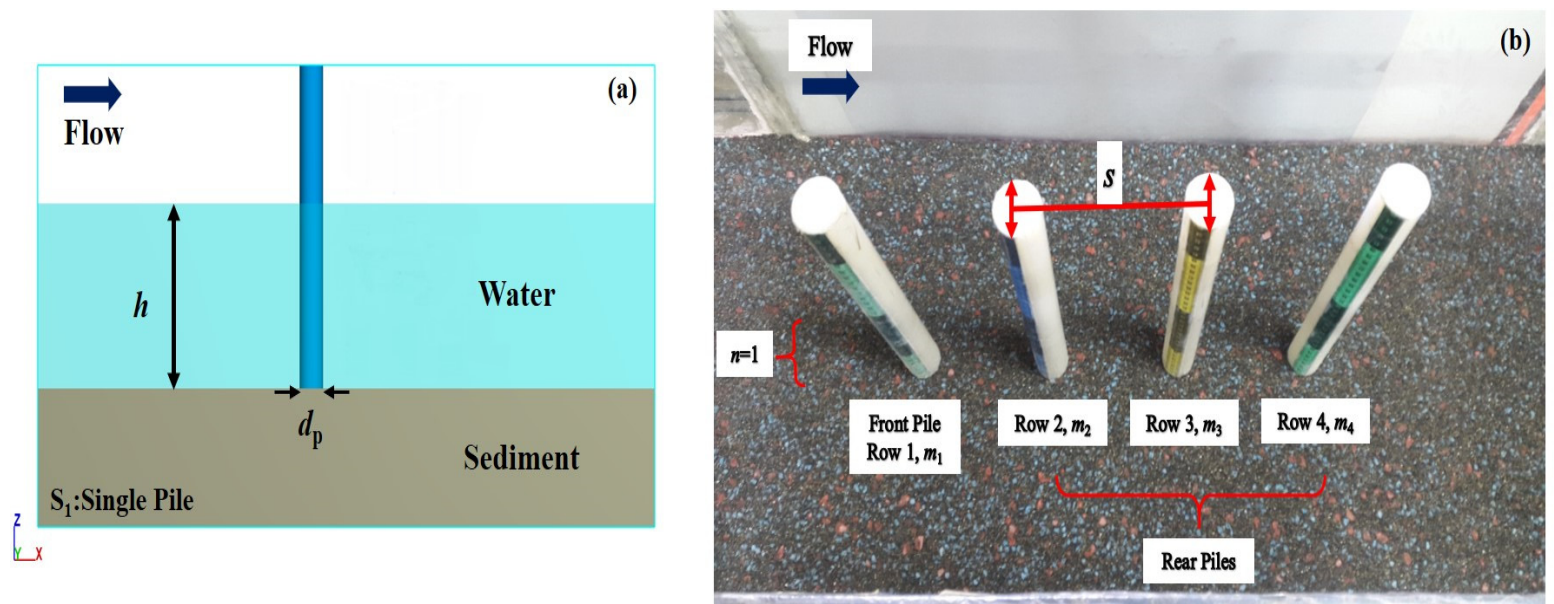

Fig. 1. Sketch plan for single pile (a) and one group of four piles in-line with the flow ( $m=4$ and $n=1)$ (b). 
Table 1. Sediment characteristics used in the present study.

\begin{tabular}{|c|c|c|c|c|c|c|}
\hline Bed configuration & $\begin{array}{c}d_{50} \\
(\mathrm{~mm})\end{array}$ & $\sigma_{\mathrm{g}}$ & $d_{*}$ & $\begin{array}{c}u_{* \mathrm{c}} \\
(\mathrm{m} / \mathrm{s})\end{array}$ & $\tau_{*_{\mathrm{c}}}$ & $d_{\mathrm{p}} / d_{50}$ \\
\hline $\mathrm{C}_{1}$ - Uniform sediment & 2.06 & $1.45<1.5$ & 50.48 & 0.0406 & 0.0426 & 19.41 \\
\hline $\mathrm{C}_{2}$ - Uniform sediment & 3.48 & $1.41<1.5$ & 85.28 & 0.055 & 0.0486 & 11.49 \\
\hline $\mathrm{C}_{3}$ - Non-uniform sediment & 1.09 & 2.08 & 26.71 & 0.0258 & 0.036 & 36.7 \\
\hline $\mathrm{C}_{4}$ - Non-uniform sediment & 1.04 & 2.98 & 25.48 & 0.0248 & 0.0357 & 38.5 \\
\hline
\end{tabular}

Note: $d *$ is dimensionless grain size of the media; $u_{*_{\mathrm{c}}}$ and $\tau_{*_{\mathrm{c}}}$ are the critical shear velocity and Shields parameter for each sediment mixture.

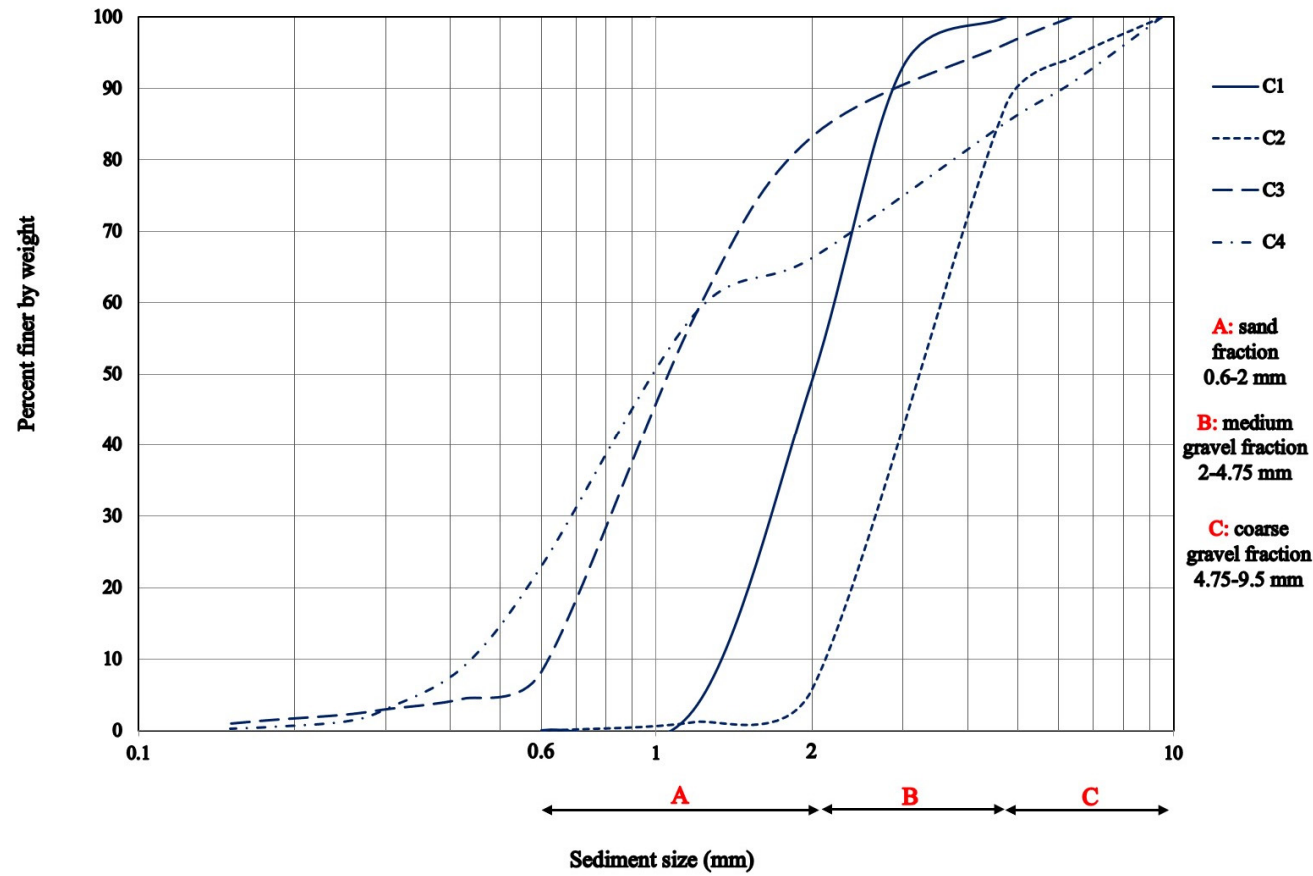

Fig. 2. Grain size gradation curve for four bed configurations $\left(\mathrm{C}_{1}-\mathrm{C}_{4}\right)$.

less than $1 \mathrm{~mm}$. In accordance, several studies have indicated that most of the scour occurs during the first 3 or $4 \mathrm{~h}$ of a test (Amini et al., 2012; Ataie-Ashtiani and Beheshti, 2006; Mia and Nago, 2003; Yanmaz and Altinbilek, 1991).

The maximum scour depth at the upstream side of each pile was measured approximately every 5 min during the first hour of the experiment. Afterward, the measurement interval was increased to $10 \mathrm{~min}$ for the second hour, and then, only two measurements were carried out each hour until the end of the experiment.

\section{RESULTS AND DISCUSSION}

\section{Data presentation and results for single-pile experiments}

Table 2 summarizes the values of control flow variables and dimensionless parameters used to characterize the experiments for the case of the single pile. For example, $\mathrm{C}_{1} \mathrm{~S}_{1} \mathrm{Q}_{1}$ indicates the experiment with the single pile $\left(\mathrm{S}_{1}\right)$ for the first defined sediment bed $\left(\mathrm{C}_{1}\right.$, see Table 1$)$ with a flow discharge of $20 \mathrm{~L} / \mathrm{s}$ $\left(Q_{1}\right)$. In order to avoid the effect of bow wave on horseshoe vortex considering the criteria of Melville and Coleman (2000) and Ballio et al. (2009), a reasonably high relative flow depth $\left(6.9 \mathrm{~cm} \leq h \leq 14.8 \mathrm{~cm} ; 20<h / d_{50}<136 ; h / d_{\mathrm{p}}>1.4\right)$ was guaranteed.

The pile diameter was less than $12 \%$ of the flume width $\left(d_{\mathrm{p}} / B \leq 0.12, B=\right.$ flume width) to prevent flow contraction
(Melville and Sutherland, 1988). From the other side, the contraction scour seemed absent since no bed degradation was observed over the cross-sections. According to Yalin (1971), the aspect ratio $B / h<5$ applies to narrow channels, therefore, the wall effect could be significant in some of the experiments (see Table 2). To check the side wall effects on the flow field, the temporal evolution of scour depth for a single pile case was compared with Oliveto and Hager's predictions (2002). A good fit was found for the time development of scour depth, thus, it seems safe to conclude that, if eventually present, side wall effects were minor in the present study.

Temporal evolution of the maximum scour depth for the four sediment beds with two different flow rates $\left(\mathrm{Q}_{1}\right.$ and $\left.\mathrm{Q}_{2}\right)$ are shown in Fig. 3. The effects of different types of sediment beds on the $d_{\mathrm{Sr} t=8 \mathrm{~h}}$ can be easily seen in Fig. 3 for both $\mathrm{Q}_{1}$ and $\mathrm{Q}_{2}$ flow conditions. Overall, the scour depth increases with time. The scour depth increases rapidly in the first $30 \mathrm{~min}$ and then slows down till reaching the equilibrium state after about $8 \mathrm{~h}$. According to Fig. 3, more than $0.65 d_{\mathrm{Sr} t=8 \mathrm{~h}}$ and $0.75 d_{\mathrm{Sr} t=8 \mathrm{~h}}$ were recorded after only $30 \mathrm{~min}$ from the beginning of the experiment with uniform and non-uniform sediments, respectively. The reduction in scour depth during the scour measurements in non-uniform sediment beds was due to the abrupt placement of individual large particles at the upstream side of the pile which could impede additional erosion until they removed from the foot of the pile. 
Table 2. Characteristic control flow variables and experimental results for the single pile.

\begin{tabular}{lcccccccccc}
\hline $\begin{array}{l}\text { Test } \\
\text { numbers }\end{array}$ & $\begin{array}{c}\text { Test } \\
\text { ID }\end{array}$ & $\begin{array}{c}h \\
(\mathrm{~m})\end{array}$ & $\begin{array}{c}u \\
(\mathrm{~m} / \mathrm{s})\end{array}$ & Fr & $\begin{array}{c}u_{\mathrm{c}} \\
(\mathrm{m} / \mathrm{s})\end{array}$ & $\begin{array}{c}u_{\mathrm{a}} \\
(\mathrm{m} / \mathrm{s})\end{array}$ & $h / d_{\mathrm{p}}$ & $d_{\mathrm{Sr}=8 h} / d_{\mathrm{p}}$ & $d_{\text {Sre }} / d_{\mathrm{p}}$ & $\begin{array}{c}l \times w^{*} \\
(\mathrm{~cm})\end{array}$ \\
\hline 1 & $\mathrm{C}_{1} \mathrm{~S}_{1} \mathrm{Q}_{1}$ & 0.09 & 0.49 & 0.51 & 0.55 & - & 2.25 & 1.53 & 1.56 & $32 \times 26$ \\
2 & $\mathrm{C}_{1} \mathrm{~S}_{1} \mathrm{Q}_{2}$ & 0.14 & 0.53 & 0.45 & 0.59 & - & 3.5 & 1.8 & 1.86 & $40 \times 30$ \\
3 & $\mathrm{C}_{2} \mathrm{~S}_{1} \mathrm{Q}_{1}$ & 0.069 & 0.58 & 0.7 & 0.65 & - & 1.73 & 0.78 & 0.87 & $14 \times 12$ \\
4 & $\mathrm{C}_{2} \mathrm{~S}_{1} \mathrm{Q}_{2}$ & 0.11 & 0.64 & 0.61 & 0.71 & - & 2.75 & 0.93 & 0.98 & $20 \times 14$ \\
5 & $\mathrm{C}_{3} \mathrm{~S}_{1} \mathrm{Q}_{1}$ & 0.092 & 0.43 & 0.46 & 0.37 & 0.48 & 2.3 & 0.95 & 1.09 & $28 \times 18$ \\
6 & $\mathrm{C}_{3} \mathrm{~S}_{1} \mathrm{Q}_{2}$ & 0.148 & 0.47 & 0.39 & 0.4 & 0.53 & 3.7 & 1.1 & 1.15 & $34 \times 19$ \\
7 & $\mathrm{C}_{4} \mathrm{~S}_{1} \mathrm{Q}_{1}$ & 0.083 & 0.48 & 0.53 & 0.37 & 0.53 & 2.08 & 0.88 & 0.91 & $18 \times 17$ \\
8 & $\mathrm{C}_{4} \mathrm{~S}_{1} \mathrm{Q}_{2}$ & 0.133 & 0.53 & 0.46 & 0.39 & 0.58 & 3.33 & 1.08 & 1.13 & $26 \times 18$ \\
\hline
\end{tabular}

Note: $l$ and $w$ are the maximum length and width of the scour hole recorded at $t=8 \mathrm{~h}$.

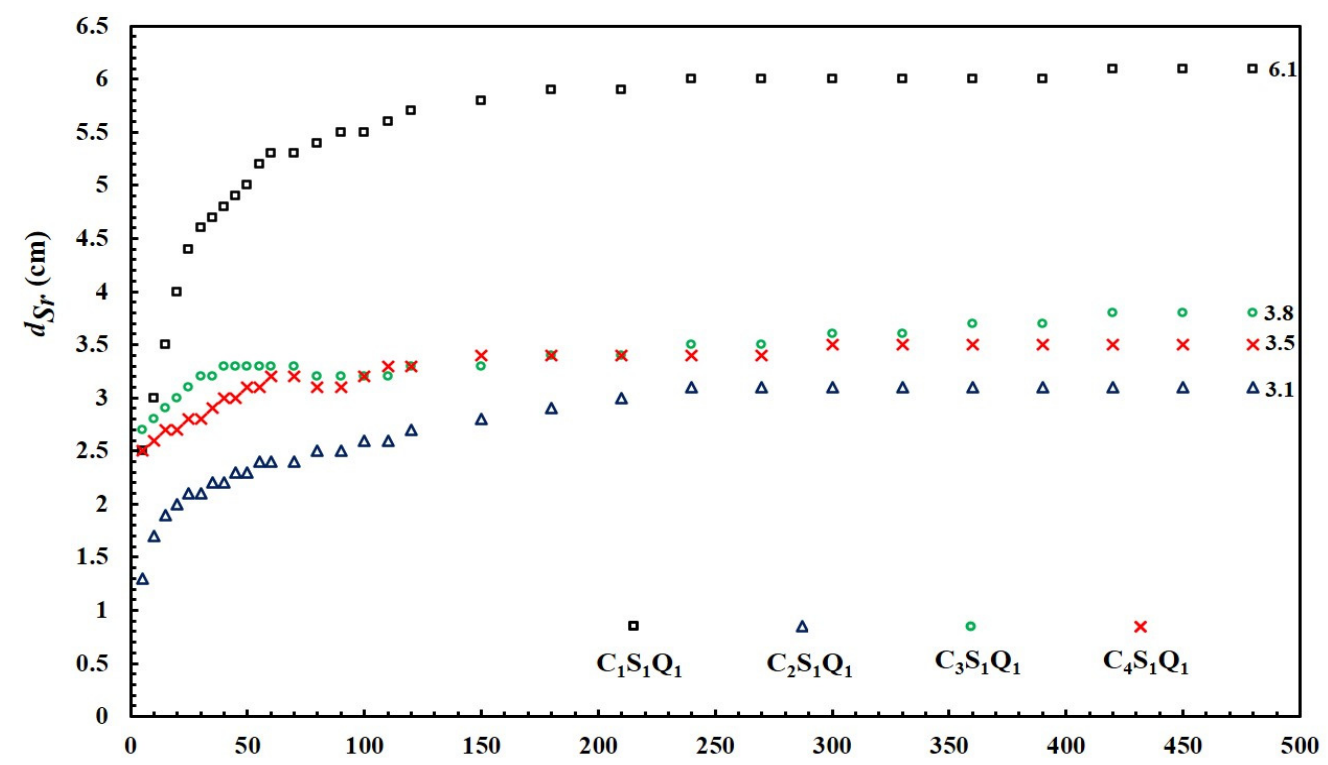

(a)

Time (min)

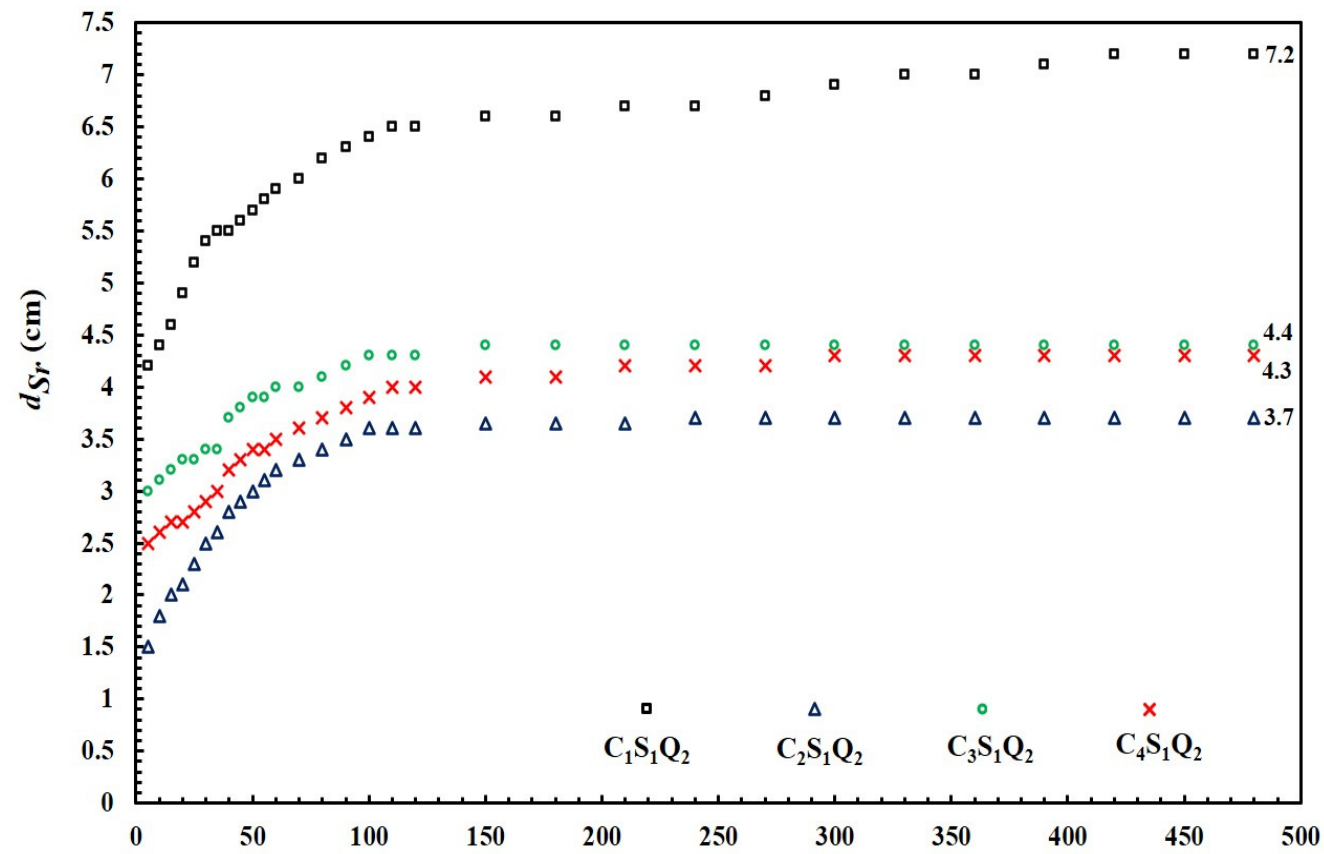

(b)

Time (min)

Fig. 3. Temporal variations of single pile scour depth for two different flow rates: a) $\mathrm{Q}_{1}=20 \mathrm{~L} / \mathrm{s}$ and b) $\mathrm{Q}_{2}=35 \mathrm{~L} / \mathrm{s}$. 
The effect of median grain size $\left(d_{\mathrm{p}} / d_{50}\right)$ on the scour depth is investigated by comparing the results obtained using the bed configuration types of $\mathrm{C}_{1} \quad\left(d_{50}=2.06 \mathrm{~mm}\right)$ and $\mathrm{C}_{2}$ $\left(d_{50}=3.48 \mathrm{~mm}\right)$ for uniform sediments. The observations revealed that an increase in $d_{50}$ (increase in $\tau_{*_{\mathrm{c}}}$ ) resulted a decrease in scour depth. When the median grain size of the material forming the bed was increased approximately from $2.06 \mathrm{~mm}$ $\left(\mathrm{C}_{1}\right)$ to $3.48 \mathrm{~mm}\left(\mathrm{C}_{2}\right)$, a decrease of approximately $49 \%$ in $d_{\mathrm{Sr} t=8 \mathrm{~h}}$ was observed for both flow conditions $\mathrm{Q}_{1}$ and $\mathrm{Q}_{2}$. However, the effects of changing the sediment beds cannot be addressed by only $d_{50}$ in non-uniform sediment mixtures. Also, the grain size distribution of the bed material and, in particular, the volume percent of sand-sized bed particles plays a significant role in the armoring process and the armor layer texture (Curran and Waters, 2014; Mir et al., 2018; Orrú et al., 2016). To incorporate the effects of grain size distribution on the maximum scour depth in non-uniform sediment mixtures, the bed material gradation should be employed.

The comparison between the bed configuration 1 and $3\left(\mathrm{C}_{1}\right.$ and $\mathrm{C}_{3}$ ) showed that the change in geometric standard deviation $\left(\sigma_{\mathrm{g}}\right)$ from, respectively, 1.45 to 2.08 (by altering the uniform sediment bed to non-uniform one), led to decreasing the maximum depth of scour by $38-39 \%$ in two corresponding flow experiments, even when the $d_{50}$ in $\mathrm{C}_{3}$ bed material was almost 1 $\mathrm{mm}$ less than $\mathrm{C}_{1}$. The reason for the reduction in scour depths is the development of an armor layer on the approach flow bed and inside of the scour hole for non-uniform sediment bed cases (visually observed during the experiments). It should be mentioned that there was not a remarkable decrease in the scour depth by the increase of the non-uniformity index (from $\mathrm{C}_{3}$ to $\mathrm{C}_{4}$ ), since two corresponding sediment types were non-uniform. Nevertheless, although the width of the scour hole is almost the same for both bed cases $\mathrm{C}_{3}$ and $\mathrm{C}_{4}$ (as presented in Table 2), the length of the scour hole decrease with an increase of $\sigma_{\mathrm{g}}$. In fact, for non-uniform sediment beds, the sediment deposition ridges began to develop immediately at the base and exit of a scour hole and increase the scour resistance to enlarge the width of the scour boundary.
From another point of view, the surface maps of topographic data for two selected experiments of $\mathrm{C}_{1} \mathrm{~S}_{1} \mathrm{Q}_{2}$ and $\mathrm{C}_{3} \mathrm{~S}_{1} \mathrm{Q}_{2}$, corresponding to the same flow $\mathrm{Q}_{2}$ but differing in the bed material $\mathrm{C}_{1}$ and $\mathrm{C}_{3}$, are shown in Fig. 4. The highest scour depth occurred upstream of the pile (Unger and Hager, 2006) for uniform sediment $\left(\mathrm{C}_{1} \mathrm{~S}_{1} \mathrm{Q}_{2}\right)$. While, for non-uniform sediment bed $\left(\mathrm{C}_{3} \mathrm{~S}_{1} \mathrm{Q}_{2}\right)$, scour is mainly due to erosion at pile sides (see Fig. 4 right), attributed to the fact that the exposure of large individual grains relative to the groove excavated in close proximity to the pile deviates flow to the lateral sides of the pile. Fig. 4 also shows a notable difference in sediment deposition pattern and scour hole geometry between the two above-mentioned experiments. In the non-uniform sediment mixture, the selective transport of the finer particles from the bed surface exposes large particles to the flow with different sizes, shapes, and orientations that lay down the bed with different positions making the surface texture asymmetric. This is the main reason for the remarkable irregularities of the bed surface detected in the eroded zone of the test $\mathrm{C}_{3} \mathrm{~S}_{1} \mathrm{Q}_{2}$ (Fig. 4 right). Furthermore, it should be noticed that fine sediments can still be winnowed at a very feeble rate through the crevices created by the larger particles of the armor layer. It means that the fine particles can be transported downstream and may rearrange the surface particles until the stable armor coat is formed.

Another aspect of the present study is the impact of different flow discharge rates (the effect of increasing flow depth with the same flow intensity) on the development of the armor layer. According to Guney et al. (2013), the armoring degree increases with an increase in the flow discharge rate. Also, the armor layer formed at the upstream flow bed was coarser in $\mathrm{Q}_{2}$ flow condition compared to $\mathrm{Q}_{1}$ in the present experiments with two different flow rates $\left(\mathrm{Q}_{1} \& \mathrm{Q}_{2}\right)$ for the same sediment beds. On the other hand, the areal development of the scour hole $(l \times w$, presented in Table 2) and the values of scour depths have increased as the flow discharge increases. For example, a comparison between the results of tests $\mathrm{C}_{4} \mathrm{~S}_{1} \mathrm{Q}_{1}$ and $\mathrm{C}_{4} \mathrm{~S}_{1} \mathrm{Q}_{2}$ indicates an increase rate of $23 \%$ in $d_{\mathrm{Sr} t=8 \mathrm{~h}}$ when the flow intensity $\left(u / u_{\mathrm{c}}\right)$ is kept the same.

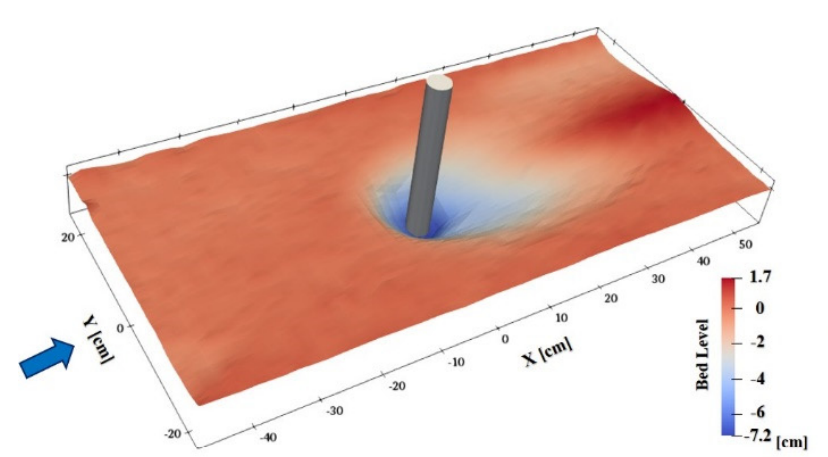

(a)

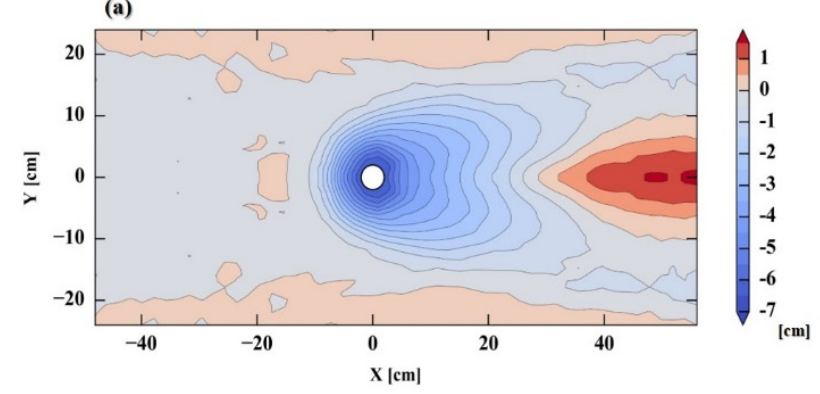

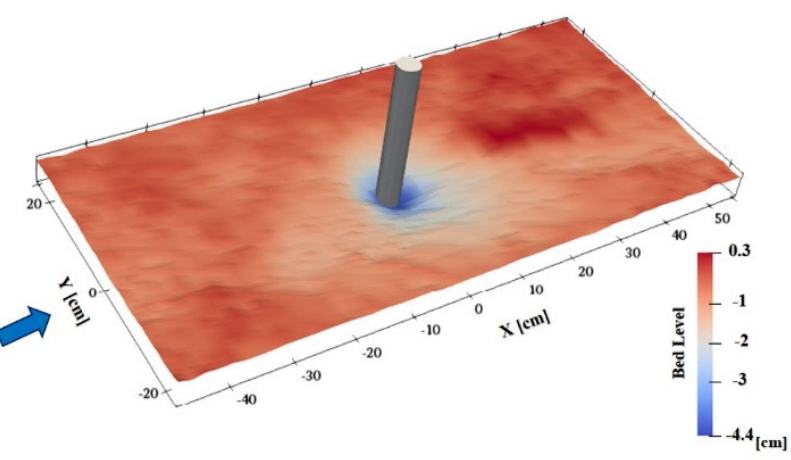

(b)

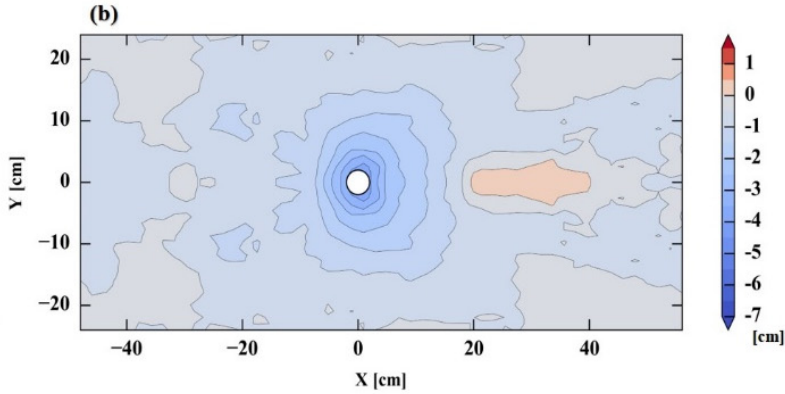

Fig. 4. Topographic map of the selected tests: a) $C_{1} S_{1} Q_{2}$ (the left column) and b) $C_{3} S_{1} Q_{2}$ (the right column). 
In order to compare the results of the present study with those obtained by scour predictors, the equilibrium scour depth must be estimated. Following the notation by Moreno et al. (2016), the equilibrium state in scour evolution can be obtained asymptotically. Hence, the recorded scour depth values through time were extrapolated to infinite time by the form of polynomial function to estimate the equilibrium scour depth, $d_{\mathrm{Sre}}$, as suggested by Lança et al. (2010). In Eq. (6), $d_{\mathrm{Sr}}$ is the scour depth at time $t$; and parameters $m_{\mathrm{i}}(i=1$ to 6$)$ are model coefficients obtained by the regression analysis. The values of root mean square error (RMSE) and determination coefficient $\left(\mathrm{R}^{2}\right)$ between measured and estimated scour depths for the 8 experimental tests ranged from $0.0445-0.0991$ and $0.82-0.99$, respectively. The values of scour depth measured at $8 \mathrm{~h}\left(d_{\mathrm{Sr} t=8 \mathrm{~h}}\right)$ and estimated equilibrium scour depths (extrapolated scour records), both normalized by the pile diameter, have also been incorporated into Table 2 .

$$
d_{\mathrm{Sr}}=m_{1}\left(1-\frac{1}{1+m_{1} m_{2} t}\right)+m_{3}\left(1-\frac{1}{1+m_{3} m_{4} t}\right)+m_{5}\left(1-\frac{1}{1+m_{5} m_{6} t}\right)
$$

Fig. 5 compares the equilibrium scour depth values estimated in this study with those obtained by the methods of Guo (2012) and Melville and Coleman (2000). In the scour equation proposed by Guo (2012), a conservative prediction for the equilibrium scour depth can be calculated using $d_{\text {Sre }}=$ $\sqrt{d_{\mathrm{p}} h} \times \tanh \left[\left(\mathrm{Fr}_{\mathrm{d}}{ }^{2} / \sigma_{\mathrm{g}}{ }^{1.5}\right) / 3.75\right]$, where $\mathrm{Fr}_{\mathrm{d}}$ is densimetric particle Froude number. To estimate $d_{\text {Sre }}$, the method of Guo (2012) includes the value of $\sigma_{\mathrm{g}}$ in the proposed predictor, while the method of Melville and Coleman (2000) (Eq. 3) takes into account the non-uniformity of sediment in terms of $u_{\mathrm{a}}$ for the calculation of $K_{\mathrm{I}}$. As pictured in Fig. 5, 100\% of the data obtained using the predictor of Guo (2012) are contained in the limits of $-20 \%$ and $+30 \%$ error, illustrating a good agreement between the predictions and measured values. The correspond- ing predictions obtained using the predictor of Melville and Coleman (2000) showed maximum 50\% overestimations compared to scour depths obtained in the present study (Fig. 5).

An important conclusion is that the predictor of Melville and Coleman (2000) may overestimate the equilibrium scour depth more than that of the predictor of Guo (2012). According to the method of Melville and Coleman (2000), the equilibrium scour depth is independent of $h$ for $h / d_{\mathrm{p}}>1.4$. This behavior is not confirmed by the present study, as can be seen in Table 2 for the experiments with two different $h / d_{\mathrm{p}}$ (here different Q). For all experimental tests, $h / d_{\mathrm{p}}$ exceeds 1.4 ; but the scour depth has increased as flow depth increases (Table 2). Furthermore, a series of experimental results in different uniform and nonuniform sediment mixtures performed by Guo (2012) showed that there is no increase in scour depth with an increase of the flow depth for $h / d_{\mathrm{p}}>6$. That is the reason for better agreement between $d_{\text {Sre }}$ calculated through the predictor of Guo (2012) and those estimated from the measured values, which involves the flow and sediment characteristics.

\section{Temporal evolution of the scour depth at piles group arrangements}

The development of scour with time at pile group arrangements is investigated for both uniform and non-uniform sediments. As it was briefly described before, the distance between center to center of two adjacent piles, $s$, varied from 2-4 pile diameter. As resumed in Table 3, 24 experimental runs were performed for the pile groups studies under the same flow conditions and sediment characteristics considered for the single pile experiments. The flow field and its interaction with sediment mixtures for pile groups depend on the values of $s / d_{\mathrm{p}}$. Pile group changes the flow structures to a great extent since the compressed horseshoe vortices in front of each rear pile interact with wake vortices developed by an upstream pile.

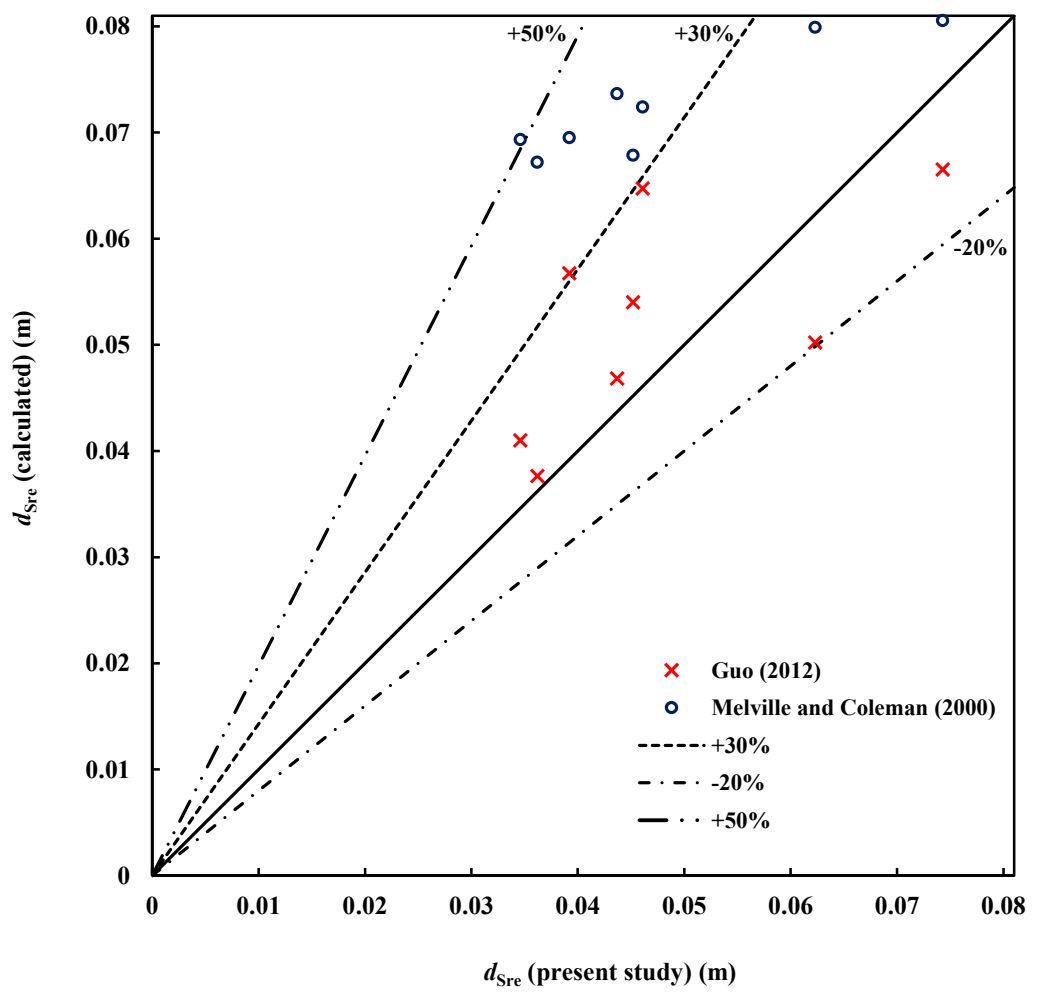

Fig. 5. Comparison between the equilibrium scour depths obtained in the present study and those calculated using the methods of Guo (2012) and Melville and Coleman (2000). 
Temporal variations of the maximum scour depth (for the flow condition $\mathrm{Q}_{2}$ ) are depicted in Fig. 6. The single pile scour time evolution is also pictured in Fig. 6 for reference. Table 3 also summarizes the recorded scour depth values after $8 \mathrm{~h}$ for four piles in the alignment (referenced in line with the flow, $d_{S 1}$ to $d_{S 4}$ ). According to the results presented in Fig. 6 , the time to get the maximum scour depth for non-uniform sediment beds would be shorter than that for uniform sediment beds due to the armoring effect of the sediment mixtures. From Fig. 6, it is clear that no significant changes in maximum scour depth were observed after one or two hours in non-uniform sediment beds, once the armor layer is formed by sorting the sediment particles. However, the typical duration needed to reach a quasiequilibrium state for uniform sediments is at least five or six hours for the studied cases (Fig. 6).

In addition to interfering wake-horseshoe vortices, flow structures are affected by piles' sheltering effects. The results indicate that in the cases with uniform sediment beds, Fig. 6 ( $a$ and $b$ ), the scour depths after $8 \mathrm{~h}$, generally decreases from the upstream pile toward the downstream one. The less scour depths, observed for downstream piles, can be explained by the fact that the flow strength and vorticity of the flow due to the pile obstacles weaken going downstream (piles' sheltering effects). Besides, material removed from around the front pile reaches the scour hole at the vicinity of the rear piles, resulting in a reduction in their scour depths. Ataie-Ashtiani and AslaniKordkandi (2013) pointed out that the approaching flow velocity to the second pile decreases to $0.2-0.3$ times the mean approach flow velocity $(u)$ due to the sheltering effect of the front pile, weakening the strength of the horseshoe vortex and resulting in reducing scour depth at the front of the downstream pile compared to the upstream pile. However, as seen in Fig. 6 ( $\mathrm{c}$ and $\mathrm{d}$ ) this pattern is not often followed in the cases with non-uniform sediment mixtures.
Unlike the uniform sediment transport which follows equal mobility of all grain sizes to the flow, the issues related to nonuniform sediment transport are rather complicated due to the sorting of a sediment bed. It could mean that the unequal threshold for the initiation of the motion of the particles in nonuniform sediments depends on the probability of particles' exposure to the flow (hiding and exposure effects), the position of particles in the bed surface, and the availability of fine particles on the bed surface layer (Mao et al., 2011). Therefore, some unexpected variations seen in scour depth evolution through time due to non-uniformity of sediments are inevitable. This situation seldom occurs in uniform sediments. Hence, sediment removal and deposition between the piles did not follow a similar pattern as with uniform sediments. However, the front pile always received maximum erosion at $8 \mathrm{~h}$ due to its greater exposure to the flow. Hence, the scour records of the front pile were extrapolated by using Eq. (6) to estimate the equilibrium scour depth for the corresponding pile group $\left(d_{\text {Sme }}\right)$. The values of $d_{\text {Sme }}$, presented in Table 3, are used for the analysis in the following sections. The range of values of RMSE and $\mathrm{R}^{2}$ are, respectively, 0.0305-0.1244 and 0.92-0.99.

\section{The evaluation of pile spacing factor for different sediment mixtures}

Fig. 7. shows the spacing correction factor, $K_{\text {Sge }}$, as a function of the normalized pile spacing $\left(s / d_{\mathrm{p}}\right)$. The spacing factor, $K_{\mathrm{Sge}}$, is the ratio of the equilibrium scour depth at pile group $\left(d_{\text {Sme }}\right)$ to that at a single cylindrical pile $\left(d_{\text {Sre }}\right)$ with the same sediment bed and flow condition. Also, the values of $K_{\mathrm{Sg}}=d_{\mathrm{Sm}(t=8 \mathrm{~h})} / d_{\mathrm{Sr}}$ were computed, representing the spacing factor obtained by maximum values of the scour depth recorded after $8 \mathrm{~h}$ (see Table 3). The values of $K_{\text {Sge }}$, presented in Table 3,

Table 3. Experimental results at piles group arrangements for various piles spacing.

\begin{tabular}{|c|c|c|c|c|c|c|c|c|c|}
\hline $\begin{array}{l}\text { Test } \\
\text { numbers }\end{array}$ & Test ID & $\begin{array}{c}s \\
(\mathrm{~cm})\end{array}$ & $\begin{array}{c}d_{\mathrm{S} 1} \\
(\mathrm{~cm})\end{array}$ & $\begin{array}{c}d_{\mathrm{S} 2} \\
(\mathrm{~cm})\end{array}$ & $\begin{array}{c}d_{\mathrm{S} 3} \\
(\mathrm{~cm})\end{array}$ & $\begin{array}{c}d_{\mathrm{S} 4} \\
(\mathrm{~cm})\end{array}$ & $\begin{array}{l}d_{\text {Sme }} \\
(\mathrm{cm})\end{array}$ & $K_{\mathrm{Sg}}$ & $K_{\text {Sge }}$ \\
\hline 1 & $\mathrm{C}_{1} \mathrm{~S}_{2} \mathrm{Q}_{1}$ & 8 & 6.1 & 5.2 & 5 & 4 & 6.74 & 1 & 1.08 \\
\hline 2 & $\mathrm{C}_{1} \mathrm{~S}_{2} \mathrm{Q}_{2}$ & 8 & 7.6 & 6.4 & 6.3 & 5.5 & 7.95 & 1.06 & 1.07 \\
\hline 3 & $\mathrm{C}_{2} \mathrm{~S}_{2} \mathrm{Q}_{1}$ & 8 & 3.6 & 2.7 & 2.4 & 2.4 & 3.79 & 1.16 & 1.1 \\
\hline 4 & $\mathrm{C}_{2} \mathrm{~S}_{2} \mathrm{Q}_{2}$ & 8 & 4.1 & 3.9 & 2.8 & 1.8 & 4.34 & 1.11 & 1.11 \\
\hline 5 & $\mathrm{C}_{3} \mathrm{~S}_{2} \mathrm{Q}_{1}$ & 8 & 4.1 & 4.1 & 3.3 & 3 & 4.26 & 1.08 & 0.97 \\
\hline 6 & $\mathrm{C}_{3} \mathrm{~S}_{2} \mathrm{Q}_{2}$ & 8 & 5.3 & 4.5 & 3.4 & 2.6 & 5.7 & 1.2 & 1.24 \\
\hline 7 & $\mathrm{C}_{4} \mathrm{~S}_{2} \mathrm{Q}_{1}$ & 8 & 3 & 3 & 2.7 & 2.3 & 3.35 & 0.86 & 0.93 \\
\hline 8 & $\mathrm{C}_{4} \mathrm{~S}_{2} \mathrm{Q}_{2}$ & 8 & 4.5 & 3.9 & 3 & 2.8 & 4.93 & 1.05 & 1.09 \\
\hline 9 & $\mathrm{C}_{1} \mathrm{~S}_{3} \mathrm{Q}_{1}$ & 12 & 5.9 & 4.5 & 4.4 & 2.8 & 6.53 & 0.97 & 1.05 \\
\hline 10 & $\mathrm{C}_{1} \mathrm{~S}_{3} \mathrm{Q}_{2}$ & 12 & 7.4 & 5.9 & 5 & 4.1 & 7.88 & 1.03 & 1.06 \\
\hline 11 & $\mathrm{C}_{2} \mathrm{~S}_{3} \mathrm{Q}_{1}$ & 12 & 3.1 & 2.3 & 1.2 & 1.1 & 3.51 & 1 & 1.01 \\
\hline 12 & $\mathrm{C}_{2} \mathrm{~S}_{3} \mathrm{Q}_{2}$ & 12 & 3.4 & 3.2 & 3 & 1.9 & 3.77 & 0.92 & 0.96 \\
\hline 13 & $\mathrm{C}_{3} \mathrm{~S}_{3} \mathrm{Q}_{1}$ & 12 & 3.3 & 2.6 & 2.1 & 1.4 & 3.4 & 0.87 & 0.78 \\
\hline 14 & $\mathrm{C}_{3} \mathrm{~S}_{3} \mathrm{Q}_{2}$ & 12 & 3.8 & 3.5 & 3.1 & 3 & 3.94 & 0.86 & 0.85 \\
\hline 15 & $\mathrm{C}_{4} \mathrm{~S}_{3} \mathrm{Q}_{1}$ & 12 & 3.1 & 1.9 & 2.7 & 1.8 & 3.25 & 0.89 & 0.9 \\
\hline 16 & $\mathrm{C}_{4} \mathrm{~S}_{3} \mathrm{Q}_{2}$ & 12 & 3.7 & 2.8 & 2.9 & 2.2 & 3.75 & 0.86 & 0.83 \\
\hline 17 & $\mathrm{C}_{1} \mathrm{~S}_{4} \mathrm{Q}_{1}$ & 16 & 5.7 & 3.6 & 3.9 & 2.4 & 5.85 & 0.93 & 0.94 \\
\hline 18 & $\mathrm{C}_{1} \mathrm{~S}_{4} \mathrm{Q}_{2}$ & 16 & 7.4 & 5.2 & 4 & 3.4 & 7.66 & 1.03 & 1.03 \\
\hline 19 & $\mathrm{C}_{2} \mathrm{~S}_{4} \mathrm{Q}_{1}$ & 16 & 2.4 & 2 & 1.3 & 1.5 & 2.46 & 0.77 & 0.71 \\
\hline 20 & $\mathrm{C}_{2} \mathrm{~S}_{4} \mathrm{Q}_{2}$ & 16 & 3.1 & 2.3 & 1.7 & 1.6 & 3.22 & 0.84 & 0.82 \\
\hline 21 & $\mathrm{C}_{3} \mathrm{~S}_{4} \mathrm{Q}_{1}$ & 16 & 3.7 & 2.8 & 2.9 & 2.8 & 3.78 & 0.97 & 0.86 \\
\hline 22 & $\mathrm{C}_{3} \mathrm{~S}_{4} \mathrm{Q}_{2}$ & 16 & 3.8 & 3.3 & 3.1 & 3.1 & 3.84 & 0.86 & 0.83 \\
\hline 23 & $\mathrm{C}_{4} \mathrm{~S}_{4} \mathrm{Q}_{1}$ & 16 & 3.7 & 2.1 & 2.5 & 2.1 & 3.73 & 1.06 & 1.03 \\
\hline 24 & $\mathrm{C}_{4} \mathrm{~S}_{4} \mathrm{Q}_{2}$ & 16 & 3.8 & 2.7 & 2.7 & 2.9 & 3.99 & 0.88 & 0.88 \\
\hline
\end{tabular}



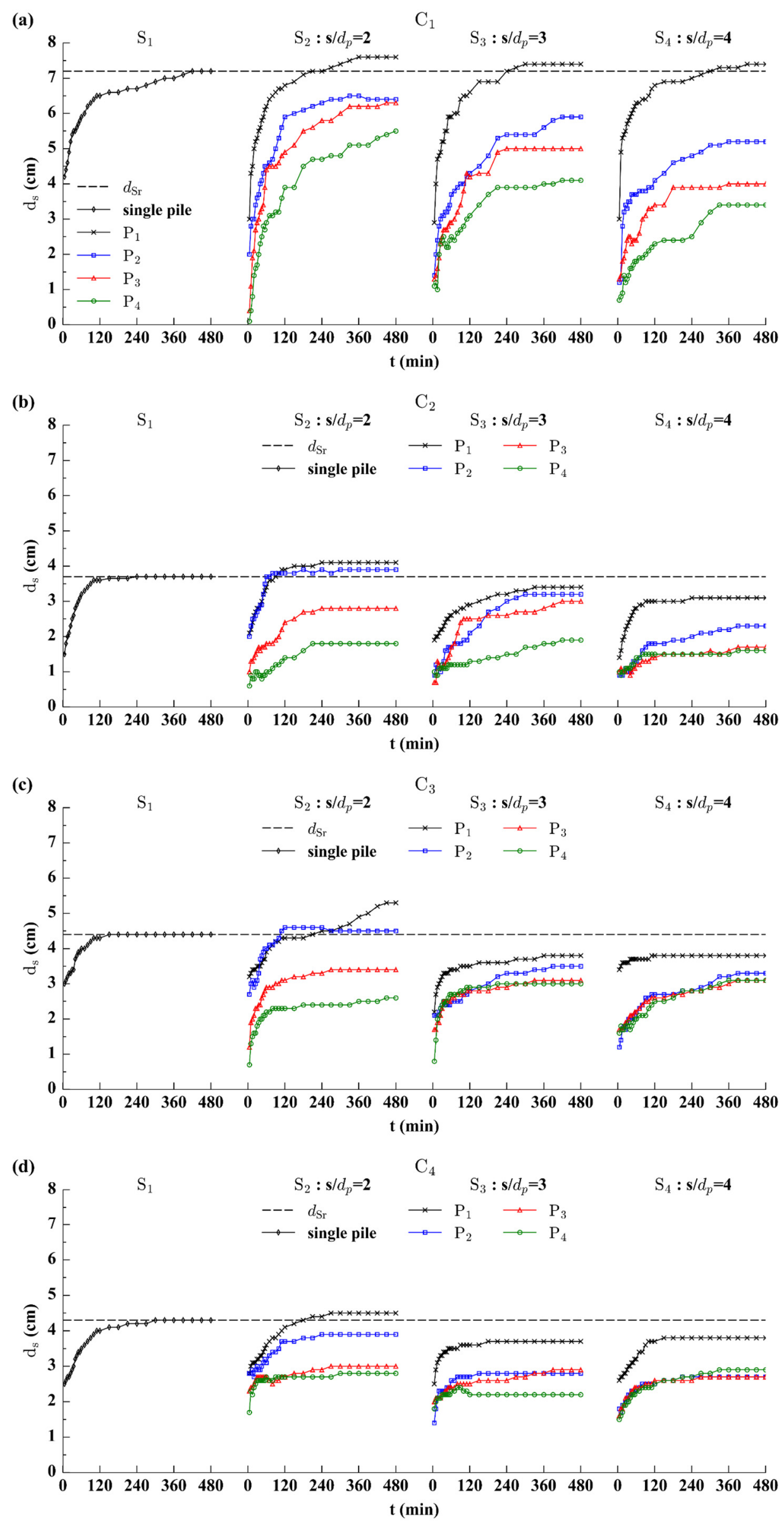

Fig. 6. Scour depth time evolution pile groups for different bed configurations (a)-(d) for the same flow condition $\left(\mathrm{Q}_{2}\right)$ and at a single reference pile. Note: $\mathrm{P}_{1}$ to $\mathrm{P}_{4}$ are the first to fourth piles in the alignment. 

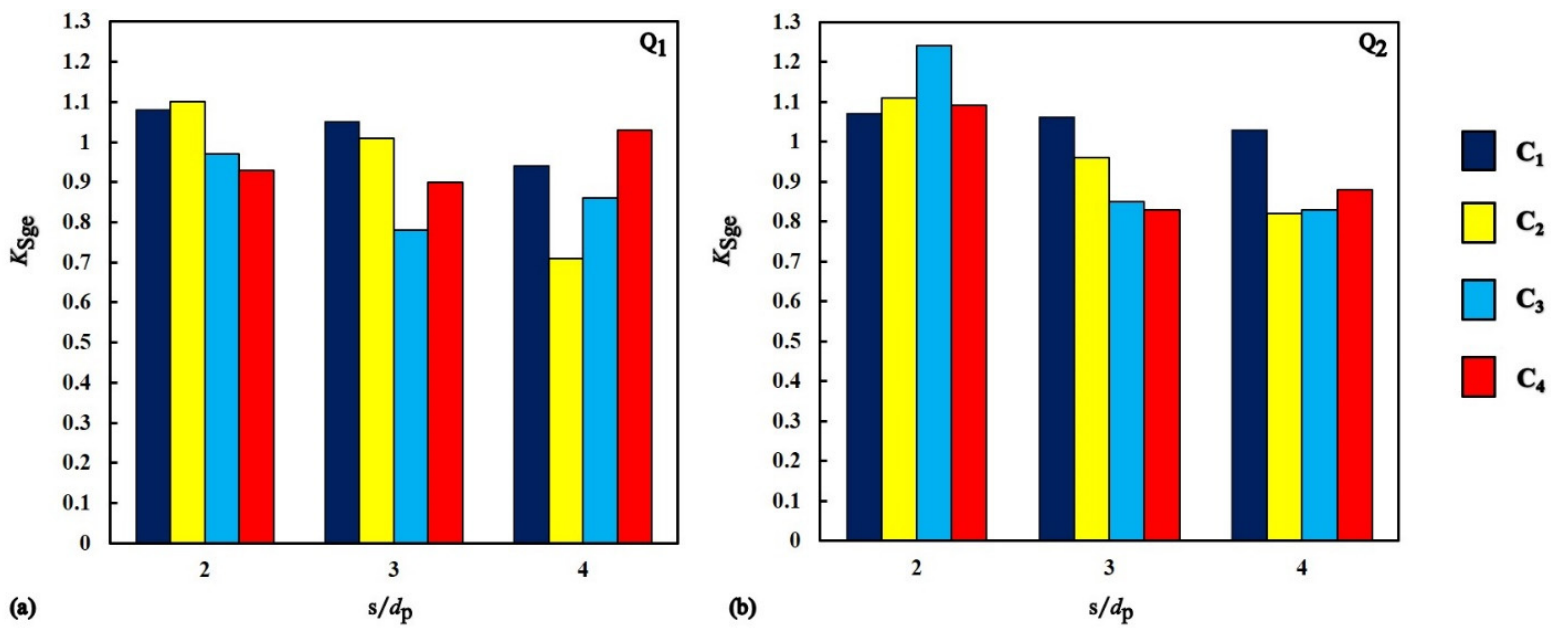

Fig. 7. Variation of $K_{\mathrm{Sge}}$ as a function of pile spacing to pile diameter $\left(s / d_{\mathrm{p}}\right)$ for different bed configurations $\left(\mathrm{C}_{1}-\mathrm{C}_{4}\right)$ and flow rates $\mathrm{Q}_{1}(\mathrm{a})$ and $\mathrm{Q}_{2}(\mathrm{~b})$.

show that for those experimental tests performed in a bed with uniformly graded material, the scour depth increases with decreasing $s / d_{\mathrm{p}}$ from 4 to 2 because of a progressive effect of wake-horseshoe vortices interactions caused by neighboring piles (Fig. 7). This is in accordance with the previous studies which have shown that the effects of compressed horseshoe vortices and wake vortex interactions between sequence piles increase as $s / d_{\mathrm{p}}$ decreases (Lança et al., 2013b; Moreno et al., 2016). According to the present results for uniform sediment bed case $\mathrm{C}_{2}$, the equilibrium scour depth at $s / d_{\mathrm{p}}=3$ and $s / d_{\mathrm{p}}=4$ are approximately $92 \%$ and $65 \%$ of that with $s / d_{\mathrm{p}}=2$ in $\mathrm{Q}_{1}$ flow condition (Fig. 7 (a)). Similar trends are observed for the other flow discharge $\left(\mathrm{Q}_{2}\right)$. The scour at $s / d_{\mathrm{p}}=3$ and $s / d_{\mathrm{p}}=4$ are approximately $87 \%$ and $74 \%$ of that with $s / d_{\mathrm{p}}=2$ (Fig. 7 (b)). Similar findings were also reported by other works, including Amini et al. (2012), Ataie-Ashtiani and Beheshti (2006), Lança et al. (2013b), and Zhou et al. (2020).

A declining trend of $d_{\text {Sme }}$ with the increase of $s / d_{\mathrm{p}}$ for uniform sediment beds was not observed in non-uniform sediment beds (Fig. 7 (a and b)). The corresponding experimental data show that scour depths have often decreased with increasing the streamwise spacing between the piles from $s / d_{\mathrm{p}}=2$ to $s / d_{\mathrm{p}}=3$ but have slightly increased from $s / d_{\mathrm{p}}=3$ to $s / d_{\mathrm{p}}=4$. According to the complex mechanism of sediment transport in non-uniform sediment mixtures as stated previously, indistinct trends in $K_{\text {Sge }}$ and $K_{\mathrm{Sg}}$ observed in the pile groups are ascribable.

In both uniform and non-uniform sediment beds, for $s / d_{\mathrm{p}} \leq 3$ a single scour hole was observed around the pile group (Fig. 8 and Fig. 9). For $s / d_{\mathrm{p}}=4$, the scour holes of each of individual piles have a tendency to be separated (as seen in Fig. 8 (c)) and interactions of vortices in piles group are no more robust. According to the present results, the individual scour hole around each pile in non-uniform sediment beds was not as clearly visible as the uniform sediment beds, due to a topographically variable bed surface (Fig. 9). For example, the visual observations for $\mathrm{C}_{3}$ bed configuration in Fig. 9 showed greater topographic variability relative to bed surface texture in Fig. 8. Also, the composition of the armor layer at the vicinity of the rear piles tend to be become unstable due to the interaction of wake vortices from the first pile with the rear piles, resulting in more energy in the wake region at the pile group (Okhravi et al., 2019).

It is important to highlight the sediment deposition mound downstream of the pile group was vanished after some hours for non-uniform mater mjials. This could be due to the partial transport of the finer sediment sizes, forming erosion pits in the bed surface (Okhravi et al., 2019). The deposited medium and relatively large particles behind the pile were then creeping into the erosion pits, remaining approximately rough and leading to a flatter bed surface downstream of the pile compared to uniform sediments.

\section{Performance of available scour depth predictors for pile group}

The estimated values of $d_{\text {Sme }}$, obtained in this study, were compared with the corresponding values obtained by the methods of Auckland (Coleman, 2005), HEC-18 (Arneson et al., 2012), and FDOT (Sheppard and Renna, 2010).

In accordance with HEC-18, Eq. (4), the effective diameter, $d_{\text {pe }}$, is given by

$d_{\mathrm{pe}}=K_{\mathrm{sp}} K_{\mathrm{m}} d_{\mathrm{p}(\mathrm{proj})}$

where $K_{\mathrm{sp}}=$ coefficient for pile spacing; $K_{\mathrm{m}}=$ coefficient for the number of aligned rows; and $d_{\mathrm{p}(\text { proj })}=$ sum of nonoverlapping projected width of the pile. For $\theta=0^{\circ}$ and $n=1$, the method estimates $K_{\mathrm{sp}}=1$ and $d_{\mathrm{pe}}=K_{\mathrm{m}} d_{\mathrm{p}}$, since $d_{\mathrm{p}(\mathrm{proj})}=d_{\mathrm{p}}$. The values of $K_{\mathrm{m}}$ were calculated using this method for the three studied pile group configurations, i.e., with different pile spacing, which accounts for the number of rows of piles in flow direction $(m)$ and their center-to-center distance between the sequence piles. The comparison between estimated $d_{\text {Sme }}$ values and the calculated values by the HEC-18 method is presented in Fig. 10. By it, it is clear that the results of HEC-18 method are highly overestimated. The explanation for the large deviations points to Eq. (4) that is independent of $d_{50}$, and the significant parameter $\sigma_{\mathrm{g}}$ is not also accounted in HEC-18 method (Arneson et al., 2012). Furthermore, the correction factor for sediment mixtures $\left(K_{\mathrm{a}}\right.$ in Eq. (4)) did not take into account the bedarmoring effects that occurred in the present study. The reason for that is the limited particle size distribution considered for calculating $K_{\mathrm{a}}$ in HEC-18 which does not cover a wide range of sediment mixtures (Molinas, 2001).

The FDOT method considers both $K_{\mathrm{sp}}$ and $K_{\mathrm{m}}$, required to calculate $d_{\text {pe }}$, equal to unity for the pile group arrangements in this study. Hence, the factor $K_{\mathrm{m}}$, used to calculate $d_{\mathrm{pe}}$ in the HEC-18 method are also used in this predictor. The results of the modified FDOT method (Fig. 10) are also overestimated 


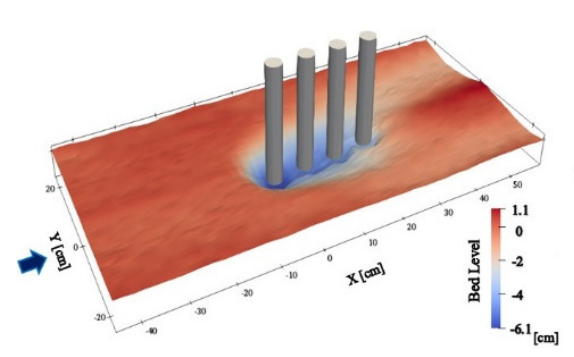

(a)

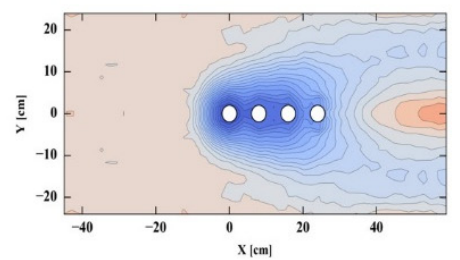

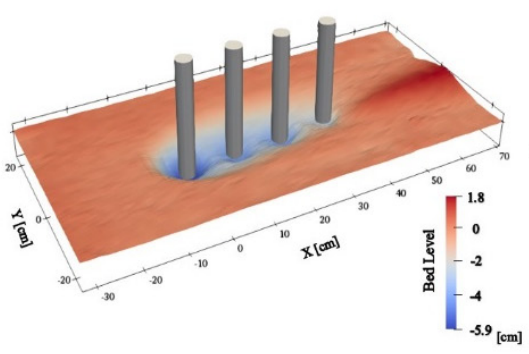

(b)

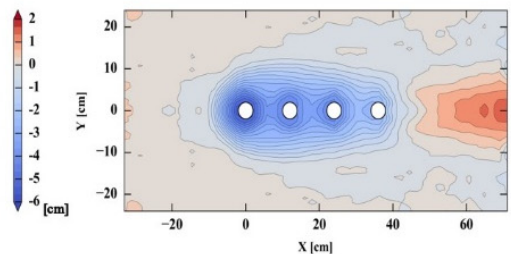

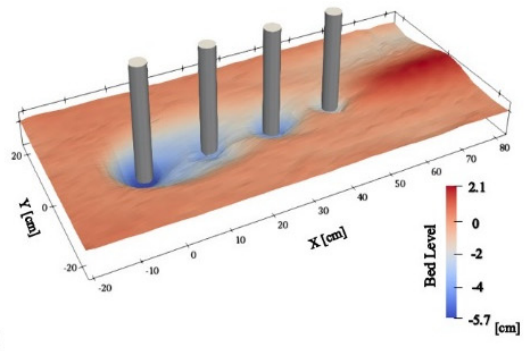

(c)

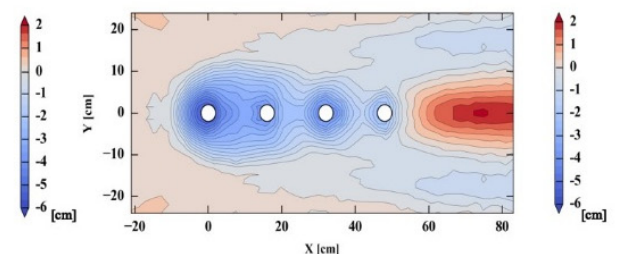

Fig. 8. Topographic map of the tests: (a) $\mathrm{C}_{1} \mathrm{~S}_{2} \mathrm{Q}_{1}$; (b) $\mathrm{C}_{1} \mathrm{~S}_{3} \mathrm{Q}_{1}$; c) $\mathrm{C}_{1} \mathrm{~S}_{4} \mathrm{Q}_{1}$.

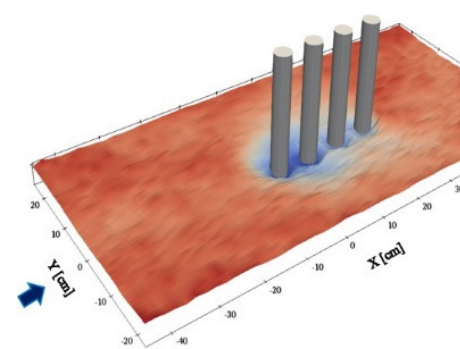

(a)

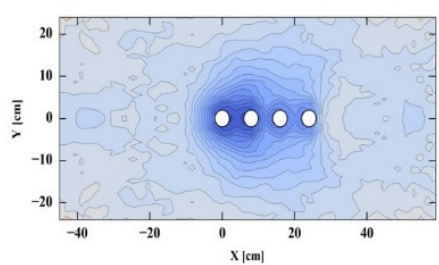

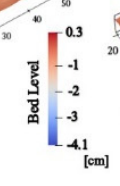

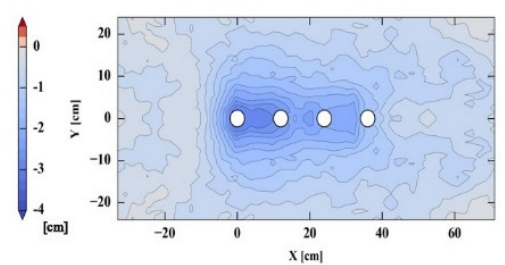

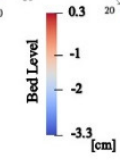

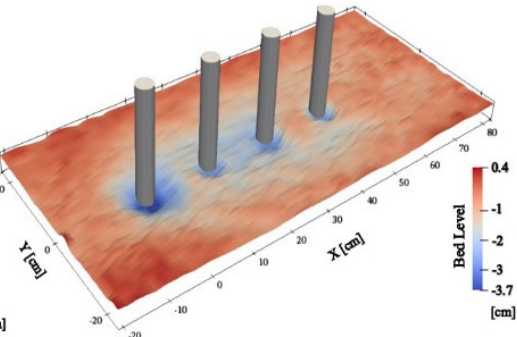

(c)

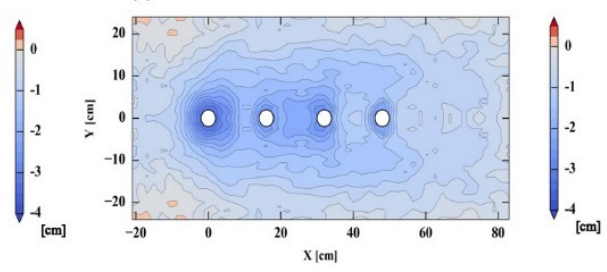

Fig. 9. Topographic map of the tests: (a) $\mathrm{C}_{3} \mathrm{~S}_{2} \mathrm{Q}_{1}$; (b) $\mathrm{C}_{3} \mathrm{~S}_{3} \mathrm{Q}_{1}$; c) $\mathrm{C}_{3} \mathrm{~S}_{4} \mathrm{Q}_{1}$.

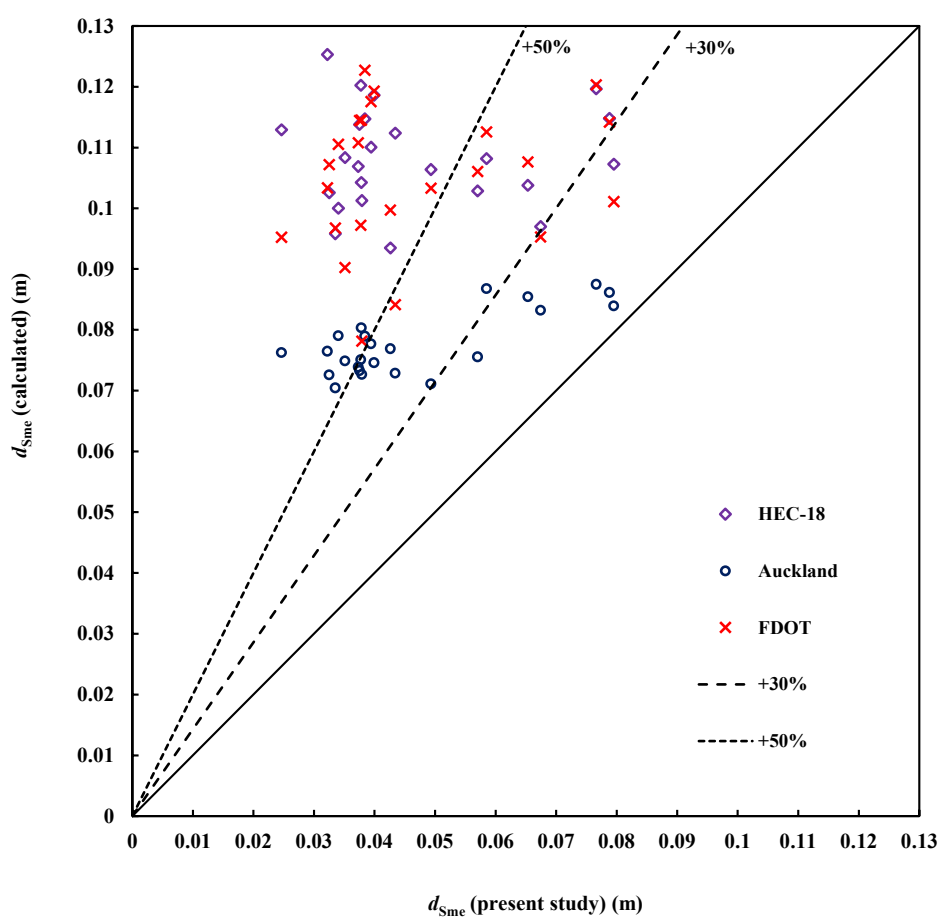

Fig. 10. Comparison between the values of $d_{\text {Sme }}$ estimated in this study with those calculated with different predictors (pile group). 
since the FDOT method neglects the armoring effect caused by the non-uniformity of the bed material.

The accuracy of the $d_{\text {Sme }}$ values obtained using the Auckland method, Eq. (3), was evaluated by the number of results contained between the line of perfect agreement (45-degree line) and a band defined by $+50 \%$, (i.e., considering an overestimation of $50 \%$ ). In the Auckland method, $66.7 \%$ of the predicted values (16/24) are surrounded by the above-referred bounds, as shown in Fig. 10. Separately, 9 out of 12 (75\%) and 7/12 (58\%) predicted values, respectively, could fit within the mentioned boundaries for uniform and non-uniform sediment bed cases. The $d_{\text {Sme }}$ values calculated by the Auckland method, Eq. (3), can be considered the most acceptable predictions for all the experimental tests in the present study. The agreement between the present findings and the results from Auckland's method is due to considering the effects of $\sigma_{\mathrm{g}}$ in the Auckland method indirectly by replacing the $d_{50}$ to $d_{50 \mathrm{a}}$ (median size of armor particles) for calculating $K_{\mathrm{d}}$, and also accounting the average approaching flow velocity at armor peak, $u_{\mathrm{a}}$, for calculating the factor of $K_{\mathrm{I}}$. Nevertheless, some major deviations (bigger than $50 \%$ ) still are observed for the Auckland method that should surely merit further investigation on future work on predictors for non-uniform sediment mixtures.

\section{CONCLUSIONS}

The focus of this study was about the effects of different sediment mixtures on the scour depth with finite time (8-hours) and infinite time (equilibrium scour depth) at a pile group (one column of four piles) with different pile spacing. In overall, the important conclusions are derived as:

- The results show that scouring process is significantly different in a complex mixture of sand and gravel beds compared to uniform sediment beds. Experiments revealed that the gradation coefficient is a controlling factor in the local pile scour. The scour depth decreased with an increase in $\sigma_{\mathrm{g}}$ due to the formation of an armor layer at the upstream side of the pile and at the scour hole, making the sediment bed more resistant to erosion. The results briefly emerged that the use of smaller $d_{50}$ (higher $d_{\mathrm{p}} / d_{50}$ ) had the same effect as decreasing $\sigma_{\mathrm{g}}$, leading to increase in the scour depth.

- The topographic map at the end of the experiments displayed the location of maximum scour depth in front and at the sides of the pile, respectively, for uniform and non-uniform sediments. In non-uniform sediments, the medium and large particles settled at the upstream side of the pile deviates flow to the lateral side of the pile that resulting in more erosion at these areas.

- The experimental measurements of $d_{\mathrm{Sr} t=8 \mathrm{~h}}$ for different flow discharge revealed that the scour depth increases as flow depth (in this case, also as flow discharge) increases for all types of granulometrias, which is not consistent with the criteria reported by Melville and Coleman (2000), which indicates that the scour depth is independent of $h$ for $h / d_{\mathrm{p}}>1.4$. While the predictor of Guo (2012) indicates closer values to the scour records in the present study by revising the above-referred ratio. The results also revealed that the effects of the sediment gradation are not constant through the different range of flow conditions and dampen with increasing the flow shallowness.

- The comparison of 8-hours evolution of scour depths for pile groups in uniform sediment beds illustrated the order of decreasing values of scour depth from the first pile to the back pile $\left(d_{\mathrm{S} 1}>d_{\mathrm{S} 2}>d_{\mathrm{S} 3}>d_{\mathrm{S} 4}\right)$. However, this trend is not often followed in non-uniform sediment beds. In non-uniform sediment mixtures, the stochastic exposure of large individual grains close to the piles reduces the local erosion and the scour depth as well. Moreover, the sediment movement mechanism is strongly dependent on the sediment packing density in nonuniform sediments.

- The effects of pile group arrangements, i.e., a single column of spaced piles, on $d_{\text {Sm }}$ were also assessed through the pile spacing factors. The analysis and evaluation of the obtained results (presented in terms of $K_{\mathrm{Sg}}$ and $K_{\mathrm{Sge}}$ ) showed that the smaller pile spacing causes a stronger interaction of wakehorseshoe vortices between the sequence piles leading to an increase of the maximum scour depth. The effect is more evident in beds with uniform sediments, while it is difficult to arrive at any trends with regard to the values of $K_{\mathrm{Sg}}$ and $K_{\mathrm{Sge}}$ for the studied pile groups in non-uniform sediment mixtures. According to the experimental observations, the authors argued that the mechanism of sediment entrainment for non-uniform sediments is practically stochastic mostly due to hidingexposure effects of different particle size fractions. Nevertheless, future studies could fruitfully scrutinize this previously unstudied issue further by contributing to the particle size distribution of the armor coat in the different pile groups.

- The comparison between the estimated values of $d_{\text {Sme }}$ versus predicted values calculated by the current well-known proposed methods (Auckland, HEC-18, and FDOT) revealed a tendency to overestimate $d_{\text {Sme }}$ values in most of the situations and give safe and conservative values, resulting in wasting of economic resources. Collectively, the present results appear consistent with the predicted values of $d_{\text {Sme }}$ by the Auckland method, since the Auckland method includes the impacts of sediment non-uniformity indirectly through nondimensionalized parameters $\left(K_{\mathrm{d}}\right.$ and $\left.K_{\mathrm{I}}\right)$. The differences to scour depths caused by complex mixtures of sediments make existing scour depth predictive methods inadequate for these sediment bed configurations. Therefore, future investigations in complex sediment beds with fine and large particles are necessary to validate the kinds of conclusions that can be drawn from this study.

Acknowledgements. The research infrastructure was provided by the Faculty of Agriculture, Bu-Ali Sina University (www.basu.ac.ir). The support of Mrs. Eshaghian in conducting the experiments is gratefully acknowledged.

\section{Data Availability Statement}

Some or all data, models, or code that support the findings of this study are available from the corresponding author upon reasonable request. (experimental flow and sediment characteristics and temporal evolution of maximum scour depth).

\section{REFERENCES}

Alemi, M., Pêgo, J.P., Maia, R., 2019. Numerical simulation of the turbulent flow around a complex bridge pier on the scoured bed. Eur. J. Mech. B Fluids., 76, 316-331.

Amini, A., Melville, B.W., Ali, T.M., Ghazali, A.H., 2012. Clear-water local scour around pile groups in shallow-water flow. J. Hydraul. Eng., 138, 2, 177-185.

Arneson, L.A., Zevenbergen, L.W., Lagasse, P.F., Clopper, P.E., 2012. Evaluating Scour at Bridges. Federal Highway Administration Hydraulic Engineering Circular No. 18. FHWA-HIF-12-003. FHWA, Washington, DC. 
Ataie-Ashtiani, B., Beheshti, A.A., 2006. Experimental investigation of clear-water local scour at pile groups. J. Hydraul. Eng., 132, 10, 1100-1104.

Ataie-Ashtiani, B., Aslani-Kordkandi, A., 2013. Flow field around single and tandem piers. Flow Turbul. Combust., 90, 3, 471-490.

Ataie-Ashtiani, B., Baratian-Ghorghi, Z., Beheshti, A.A., 2010. Experimental investigation of clear-water local scour of compound piers. J. Hydraul. Eng., 136, 6, 343-351.

Ballio, F., Teruzzi, A., Radice, A., 2009. Constriction effects in clear-water scour at abutments. J. Hydraul. Eng., 135, 2, 140-145.

Chiew, Y.M., Melville, B.W., 1989. Local scour at bridge piers with non-uniform sediments. Proc. Inst. Civ. Engrs., 87, 2, 215-224.

Coleman, S.E., 2005. Clearwater local scour at complex piers. J. Hydraul. Eng., 131, 4, 330-334.

Curran, J.C., Waters, K.A., 2014. The importance of bed sediment sand content for the structure of a static armor layer in a gravel bed river. J. Geophys. Res. Earth Surf., 119, 7, 1484-1497.

Diab, R.M.A.E.A., 2011. Experimental investigation on scouring around piers of different shape and alignment in gravel. Ph.D. thesis. Department of Civil and Environmental Sciences, Technical University Darmstadt, Germany.

Ettema, R., Constantinescu, G., Melville, B.W., 2017. Flowfield complexity and design estimation of pier-scour depth: Sixty years since Laursen and Toch. J. Hydraul. Eng., 143, 9, 03117006. https://doi.org/10.1061/(ASCE)HY.19437900.0001330

Ettema, R., Melville, B.W., Constantinescu, G., 2011. Evaluation of bridge scour research: Pier scour processes and predictions. Transportation Research Board of the National Academies, Washington, DC.

Dey, S., Raikar, R.V., 2005. Scour in long contractions. J. Hydraul. Eng., 131, 12, 1036-1049.

Guney, M.S., Bombar, G., Aksoy, A.O., 2013. Experimental study of the coarse surface development effect on the bimodal bed-load transport under unsteady flow conditions. J. Hydraul. Eng., 139, 1, 12-21.

Guo, J., 2012. Pier scour in clear water for sediment mixtures. J. Hydraul. Res., 50, 1, 18-27.

Lança, R., Fael, C., Cardoso, A., 2010. Assessing equilibrium clear water scour around single cylindrical piers. In: Dittrich, A., Koll, K., Aberle, J., Geisenhainer, P. (Eds.): Proc. River Flow. Bundesanstalt für Wasserbau, Karlsruhe, Germany, pp. 1207-1213.

Lança, R., Fael, C., Maia, R., Pêgo, J.P., Cardoso, A.H., $2013 a$. Clear-water scour at comparatively large cylindrical piers. J. Hydraul. Eng., 139, 11, 1117-1125.

Lança, R., Fael, C., Maia, R., Pêgo, J.P., Cardoso, A.H., 2013 b. Clear-water scour at pile groups. J. Hydraul. Eng., 139, 10, 1089-1098.

Laursen, E.M., 1963. An analysis of relief bridge scour. J. Hydraulics Div., 89, 3, 93-118.

Lee, S.O., Sturm, T.W., 2009. Effect of sediment size scaling on physical modeling of bridge pier scour. J. Hydraul. Eng., 135, 10, 793-802.

Mao, L., Cooper, J.R., Frostick, L.E., 2011. Grain size and topographical differences between static and mobile armour layers. Earth Surf. Process. Landf., 36, 10, 1321-1334.

Melville, B.W., Chiew, Y.M., 1999. Time scale for local scour at bridge piers. J. Hydraul. Eng., 125, 1, 59-65.

Melville, B.W., Coleman S.E., 2000. Bridge Scour. Water Resources Publications, Highlands ranch, Colorado, USA.
Melville, B.W., Sutherland, A.J., 1988. Design method for local scour at bridge piers. J. Hydraul. Eng., 114, 10, 1210-1226.

Mia, M.F., Nago, H., 2003. Design method of time-dependent local scour at circular bridge pier. J. Hydraul. Eng., 129, 6, 420-427.

Mir, B.H., Lone, M.A., Bhat, J.A., Rather, N.A., 2018. Effect of gradation of bed material on local scour depth. Geotech. Geol. Eng., 36, 4, 2505-2516.

Molinas, A., 2001. Effects of gradation and cohesion on bridge scour: Synthesis report. Report No. FHWA-RD-99-189. Federal Highway Administration, Washington, DC.

Moreno, M., Maia, R., Couto, L., 2016. Prediction of equilibrium local scour depth at complex bridge piers. J. Hydraul. Eng., 142, 11, 04016045.

Namaee, M.R., Sui, J., 2019. Impact of armour layer on the depth of scour hole around side-by-side bridge piers under ice-covered flow condition. J. Hydrol. Hydromech., 67, 3, 240-251.

Okhravi, S., Gohari, S., Maia, R., 2019. Scour development under different flow rates for sediment mixtures. In: Proc. $3^{\text {rd }}$ Doctoral Congress in Engineering, Symposium of Civil Engineering and Spatial Planning, FEUP, 27-28 June, Porto, Portugal.

Oliveto, G., Hager, W.H., 2002. Temporal evolution of clearwater pier and abutment scour. J. Hydraul. Eng., 128, 9, 811-820.

Orrú, C., Blom, A., Uijttewaal, W.S.J., 2016. Armor breakup and reformation in a degradational laboratory experiment. Earth Surf. Dyn., 4, 2, 461-470.

Richardson, E.V., Davis, S.R., 2001. Evaluating scour at bridges. Hydraulic Engineering Circular No. 18 (HEC-18). Rep. No. FHWA NHI 01-001. Federal Highway Administration, Washington. DC.

Raudkivi, A.J., Ettema, R., 1977. Effect of sediment gradation on clear water scour. J. Hydraulics Div., 103, 10, 12091213.

Sheppard, D.M., Odeh, M., Glasser, T., 2004. Large scale clearwater local pier scour experiments. J. Hydraul. Eng., 130, 10, 957-963.

Sheppard, D.M., Renna, R., 2010. Bridge Scour Manual. Florida Department of Transportation, Tallahassee, FL.

Sui, J., Afzalimehr, H., Samani, A.K., Maherani, M., 2010. Clear-water scour around semi-elliptical abutments with armored beds. Int. J. Sediment. Res., 25, 3, 233-245.

Sumer, B.M., Fredsøe, J., 2002. The Mechanics of Scour in the Marine Environment. World Scientific, Singapore, 539 p.

Unger, J., Hager, W.H., 2006. Down-flow and horseshoe vortex characteristics of sediment embedded bridge piers. Exp. Fluids, 42, 1, 1-19.

Wilcock, P.R., DeTemple, B.T., 2005. Persistence of armor layers in gravel-bed streams. Geophys. Res. Lett., 32, 8, L08402. https://doi.org/10.1029/2004GL021772

Yalin, M.S., 1971. Theory of Hydraulic Models. MacMillan Civil Engineering Hydraulics, Macmillan.

Yang, Y., Melville, B.W., Macky, G.H., Shamseldin, A.Y., 2020. Experimental study on local scour at complex bridge pier under combined waves and current. Coast. Eng., 160, 103730. https://doi.org/10.1016/j.coastaleng.2020.103730

Yanmaz, A.M., Altinbilek, H.D., 1991. Study of timedependent local scour around bridge piers. J. Hydraul. Eng., 117, 10, 1247-1268.

Zhou, K., Duan, J.G., Bombardelli, F.A., 2020. Experimental and theoretical study of local scour around three-pier group. J. Hydraul. Eng., 146, 10, 04020069. https://doi.org/10.1061/(ASCE)HY.1943-7900.0001794 


\section{NOMENCLATURE}

B flume width;

C configuration of sediment bed mixtures;

$d_{\mathrm{p}}$ individual pile width or diameter;

$d_{\mathrm{pe}}$ equivalent pile width or diameter;

$d_{\mathrm{p}(\mathrm{proj})}$ sum of the non-overlapping widths of the individual piles projected on a plane normal to the flow direction;

$d_{50}$ median diameter of sediment particles forming the bed;

$d_{50 \mathrm{a}}$ median size of armor particles;

$d_{*}$ dimensionless grain size;

$d_{\mathrm{S} 1}, d_{\mathrm{S} 2}, d_{\mathrm{S} 3}, d_{\mathrm{S} 4}$ maximum scour depth after $8 \mathrm{~h}$ for the sequence piles in the alignment;

$d_{\mathrm{Sm}}$ maximum scour depth at instant $t$ for a group of piles;

$d_{\text {Sme }}$ pile group equilibrium scour depth;

$d_{\mathrm{Sr}}$ maximum scour depth at instant $t$ for a single reference pile;

$d_{\text {Sre }}$ equilibrium scour depth at a single reference pile;

Fr Froude number;

$\mathrm{Fr}_{\mathrm{d}}$ densimetric particle Froude number;

g gravitational acceleration;

$h$ upstream flow depth (Fig. 1);

$K_{\mathrm{a}}$ factor for sediment mixtures;

$K_{\text {bed }}$ factor for bed form condition;

$K_{\mathrm{d}}=d_{\mathrm{p}} / d_{50}$ sediment coarseness, factor of sediment size;

$K_{\mathrm{h}}=h / d_{\mathrm{p}}$ flow shallowness, factor of flow depth-pile size;

$K_{\mathrm{I}}=u / u_{\mathrm{c}}$ factor of flow intensity;

$K_{\mathrm{m}}$ coefficient for number of aligned rows;

$K_{\text {Sg }}$ pile group factor associated with pile spacing at a given $t$;

$K_{\text {Sge }}$ pile group factor associated with pile spacing at

equilibrium time;
$K_{\mathrm{s}}$ pile shape factor;

$K_{\text {sp }}$ pile group spacing factor;

$K_{\mathrm{t}}$ factor of time;

$K_{\theta}$ skew-angle factor;

$l$ maximum length of the scour hole;

$m$ number of piles in the alignment (Fig. 1);

$n$ number of pile column in the group (Fig. 1);

$m_{\mathrm{i}(\mathrm{i}=1-6)}$ regression coefficients;

$\mathrm{P}_{1}, \mathrm{P}_{2}, \mathrm{P}_{3}$ and $\mathrm{P}_{4}$ represented upstream to downstream piles in the alignment;

Q flow discharge (L/s);

$\mathrm{S}_{1}$ the situation representing a single pile;

$\mathrm{S}_{2}, \mathrm{~S}_{3}$, and $\mathrm{S}_{4}$ the situations in a pile group when $s / d_{\mathrm{p}}=2$,

$s / d_{\mathrm{p}}=3$, and $s / d_{\mathrm{p}}=4$, respectively;

$s$ pile spacing (Fig. 1);

$t$ time (s);

$u$ average approach flow velocity;

$u_{\mathrm{a}}$ average approaching velocity at armor peak;

$u_{\mathrm{c}}$ ultimate mean flow velocity for uniform sediment

entrainment;

$u *_{\mathrm{c}}$ critical shear velocity for median size of $d_{50}$;

$w$ maximum width of the scour hole;

$\theta$ pile group skew-angle;

$\varphi$ generic function;

$\rho$ density of water;

$\rho_{\mathrm{s}}$ density of sediment;

$\tau_{*_{\mathrm{c}}}$ Shields parameter; and

$\sigma_{\mathrm{g}}$ sediment non-uniformity (gradation coefficient).

Received 5 April 2021

Accepted 23 September 2021 